\title{
Idaho Chemical Processing Plant and Plutonium-Uranium Extraction Plant Phaseout/Deactivation Study
}

Prepared for the U.S. Department of Energy Office of Environmental Restoration and Waste Management

(2) Westinghouse

Hanford Operations and Engineering Contractor for the

U S Department of Energy under Contract DE AC06.87RL10930

Approved for Public Release 


\section{LEGAL DISCLAIMER}

This report was prepared as an account of work sponsored by an agency of the United States Government. Neither the United States Government nor any agency thereof, nor any of their employees, nor any of their contractors, subcontractors or their employees, makes any warranty, express or implied, or assumes any legal liability or responsibility for the accuracy, completeness, or any third party's use or the results of such use of any information, apparatus, product, or process disclosed, or represents that its use would not infringe privately owned rights. Reference herein to any specific commercial product, process, or service by trade name, trademark, manufacturer, or otherwise, does not necessarily constitute or imply its endorsement, recommendation, or favoring by the United States Government or any agency thereof or its contractors or subcontractors. The views and opinions of authors expressed herein do not necessarily state or reflect those of the United States Government or any agency thereot.

This report has been reproduced from the best available copy.

Printed in the Unitod States of America

DISCLM-2.CHP $(1.91)$ 


\section{Idaho Chemical Processing Plant and Plutonium-Uranium Extraction Plant Phaseout/ Deactivation Study}

\section{W. Patterson}

Westinghouse Idaho Nuclear Company

R. J. Thompson

Westinghouse Hanford Company

Date Published

January 1994

Prepared for the U.S. Department of Energy Office of Environmental Restoration and Waste Management

\footnotetext{
(2) Westinghouse Hanford Company Richland, Washington 99352

Hanford Operations and Engineering Contractor for the

U.S. Department of Energy under Contract DE-AC06-87RL 10930
}

Approved for Public Release 


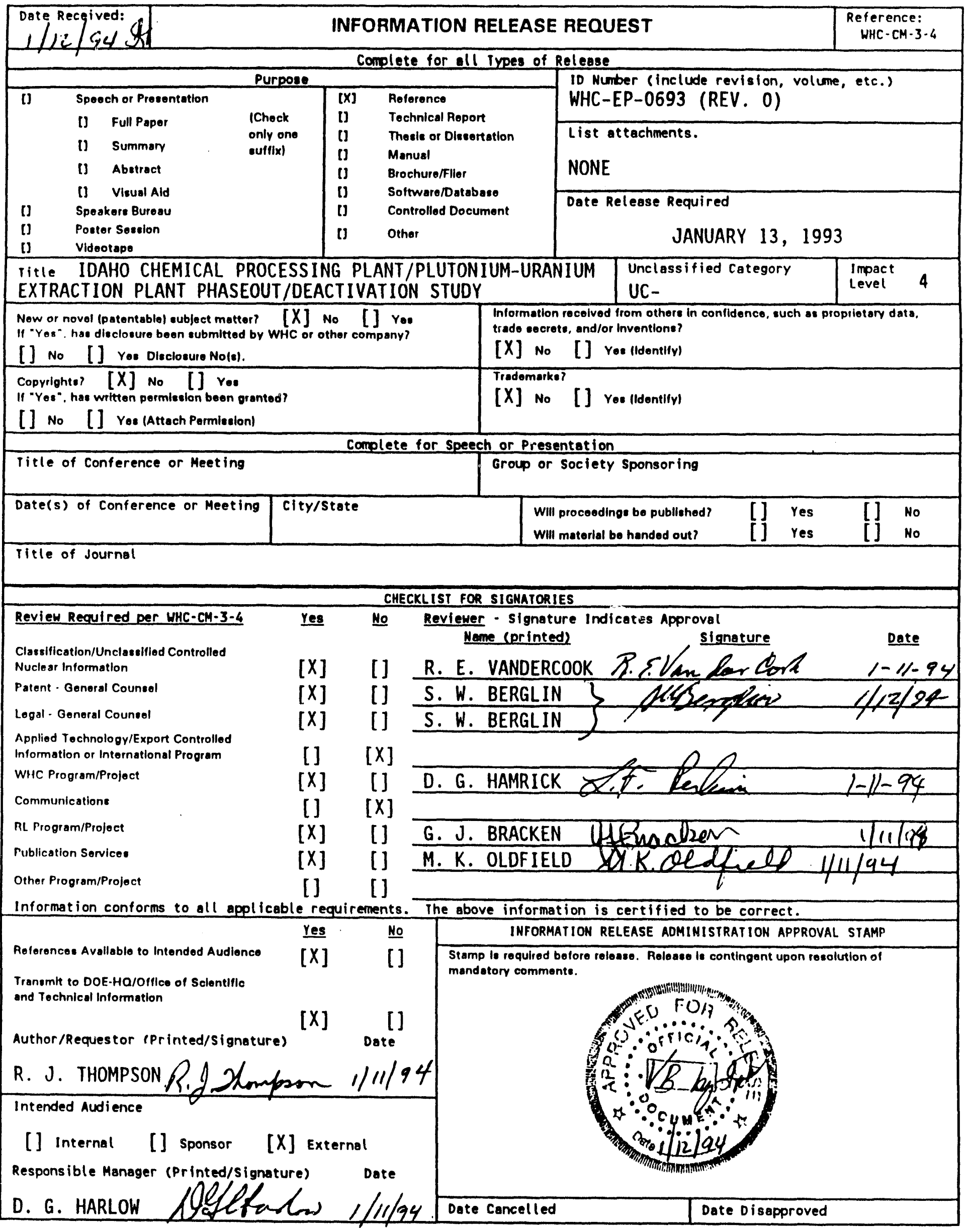


Document Title: Idaho Chemical Processing Plant and Plutonium-Uranium Extraction Plant Phaseout/Deactivation Study

Prepared By:

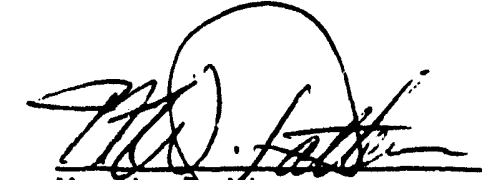

M. W. Patterson

Westinghouse Idaho Nuclear Company

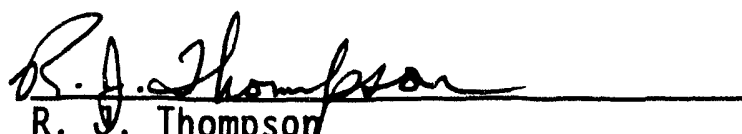

R. J. Thompson

Westinghouse Hanford Company

Approved By:

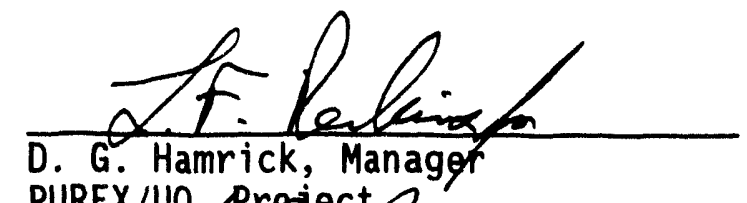
PUREX/UO Project/?

K. E. Ryan, Tapager

Separations/Material Management

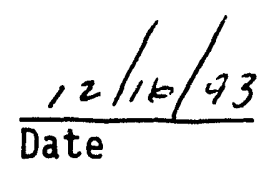

$\frac{12 / 16 / 93}{\text { Date }}$

$\frac{1 / 11 / 94}{\text { Date }}$

$\frac{12 / 16 / 03}{\text { Date }}$ 


\section{EXECUTIVE SUMMARY}

The decision to cease all U.S. Department of Energy (DOE) reprocessing of nuclear fuels was made on April 28, 1992. This study provides insight into and a comparison of the management, technical, compliance, and safety strategies for deactivating the Idaho Chemical Processing Plant (ICPP) at Westinghouse Idaho Nuclear Company (WINCO) and the Westinghouse Hanford Company (WHC) Plutonium-Uranium Extraction (PUREX) Plant. The purpose of this study is to ensure that lessons-learned and future plans are coordinated between the two facilities.

End State. The PUREX Plant and the Uranium-Trioxide Plant $\left(\mathrm{UO}_{3}\right)$ will be in a surveillance status ready for decontamination and decommissioning. Both plants will be locked and employ normal industrial practices with minimal electrical service for quarterly surveillance. PUREX will maintain only minimal canyon ventilation.

At the ICPP, fuel reprocessing systems and associated facilities will be placed in a phased-out status (no fuel dissolution or uranium recovery) with interface activities continuing to support waste management, analytical, and fuel storage activities. A transition plan is being prepared to characterize ICPP fuel processing facilities for future uses or proceeding with decontamination and decommissioning.

While the PUREX Plant deactivation end state and the ICPP fuel reprocessing phaseout end state are slightly different, they share the same objective, to cease reprocessing fuel.

Technical Comparison. The original missions for the PUREX PIant and ICPP differed significantly. The primary mission of the ICPP was to recover highly enriched uranium, while the primary mission of PUREX was to recover plutonium. Consequently, there were significant differences in nuclear fuel input and composition, physical size of the plants, and product output. However, the plants have many similar unit operations.

The most significant difference between deactivating PUREX/UO 3 and phasing out fuel reprocessing at ICPP is that PUREX $/ \mathrm{UO}_{3}$ Can be isolated from other site activities while fuel reprocessing at ICPP is closely integrated with other site activities (i.e., waste management, fuel storage, and analytical chemistry).

Saving Through Sharing. The greatest opportunity for savings through sharing is to avoid repeating activities at the two sites (i.e., sharing lessons-learned). The ICPP staff has already taken advantage of PUREX's transition-to-standby by establishing the ICPP Phaseout Plan through independent review by WHC. However, specific activities such as using excess chemicals are also advantageous. PUREX has shipped excess chemicals (specifically, aluminum nitrate nonahydrate) that were used in the ICPP process. Other excess chemicals, such as PUREX organic, are potentially usable at ICPP. 
The phaseout/deactivation plans for the plants are expected to be revised as lessons learned and stakeholder input are received. As detailed plans for specific activities are developed and GOCO site exchanges occur, additional savings through sharing are expected.

The Westinghouse Government-Owned Contractor-Operated (GOCO) committee on facility transition, which was initiated by Westinghouse Electric Corporation (WEC), is a key activity to ensure that savings through sharing occurs. The committee is made up of representatives from all GOCO WEC contractors and forms the basis for the managerial, technical, and compliance interfaces.

Stakeholder Involvement. Westinghouse Hanford Company and Westinghouse Idaho Nuclear Company are committed to involving of all stakeholders. Current1y, extensive communication efforts use local news media, workshops, organizational meetings, and internal company mechanisms. The continued success of these activities depends on stakeholder involvement. 


\section{CONTENTS}

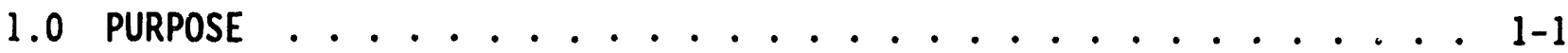

2.0 MANAGEMENT APPROACH ........................ 2-1

2.1 PROJECT/PROGRAM PLANS ..................... . . . . $2-1$

2.2 ORGANIZATION ..................... . . . . . .

2.3 PROJECT/PROGRAM CONTROL SYSTEM .............. . $2-3$

2.4 STAKEHOLDER INVOLVEMENT . . . . . . . . . . . . . . . . 2-3

2.5 APPROACH TO END-STATE DEFINITION ............... . . 2-8

2.5.1 PUREX $/ \mathrm{UO}_{3}$ Deactivation Project End State . . . . . . . 2-8

2.5.2 ICPP Phaseout End State ............. . 2-9

3.0 FACILITY TECHNICAL COMPARISON . . . . . . . . . . . . . . 3-1

3.1 OPERATIONAL TECHNICAL COMPARISON ................ $3-11$

3.2 POSSIBLE FUTURE USE . . . . . . . . . . . . . . . . . 3-17

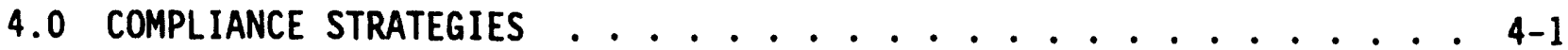

5.0 SAFETY DOCUMENTATION STRATEGY . . . . . . . . . . . . . . . . . 5-1

5.1 CURRENT FINAL SAFETY ANALYSIS REPORT STATUS ........... $. .5-1$

5.2 SAFETY DOCUMENTATION FOR TRANSITION ............... . . . 5 . 5

5.3 KEY RISKS AND HAZARDS .................... 5-3

6.0 WASTE MANAGEMENT . . . . . . . . . . . . . . . . . . . 6-1

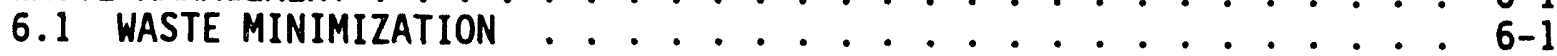

7.0 SAVINGS THROUGH SHARING ...................... . . . . .

8.0 REFERENCES . . . . . . . . . . . . . . . . . . . 8-1 


\section{WHC-EP-0693 Rev. 0}

\section{LIST OF FIGURES}

1 PUREX $/ \mathrm{UO}_{3}$ Deactivation Project/DOE/WHC Management Relationships . . . 2-2

2 PUREX $/ \mathrm{UO}_{3}$ Transition Project Work Breakdown Structure . . . . . . . . 2-4

3 Plan Views of the PUREX Plant (202-A Building) . . . . . . . . . 3-2

4 Aerial Photograph of the PUREX Plant . . . . . . . . . . . . . 3-3

5 PUREX $/ \mathrm{UO}_{3}$ Deactivation Project PUREX Yard Plan . . . . . . . . . . . 3-4

6 Aerial Photograph of the $\mathrm{UO}_{3}$ Plant . . . . . . . . . . . . 3-6

7 PUREX $/ \mathrm{UO}_{3}$ Deactivation Project $-\mathrm{UO}_{3}$ Plant Yard Plan . . . . . . . 3-7

8 Aerial View of ICPP Site . . . . . . . . . . . . . . 3-8

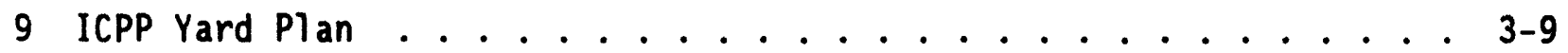

10 Floor Plan View of ICPP Separations Facilities . . . . . . . . 3-10

11 Transition USQ Process . . . . . . . . . . . . . . . . 5-4

\section{LIST OF TABLES}

1 A Comparison of Management Control Systems for PUREX and ICPP . . . 2-5

2 Stakeholder/Project Communication . . . . . . . . . . . . 2-6

3 End-State Key Features Comparison . . . . . . . . . . . . . 2-9

4 Technical Comparison .. . . . . . . . . . . . . . . 3-12

5 Comparison of Waste Management Activities . . . . . . . . . . 6-2 


\title{
LIST OF TERMS
}

\author{
DOE \\ FDP \\ FSAR \\ U. S. Department of Energy \\ Fluorinel dissolution process \\ Final Safety Analysis Report \\ GOCO \\ Government-Owned Contractor-Operated \\ $\mathrm{HQ}$ \\ ICPP \\ MCS \\ NEPA \\ OSR \\ PSD \\ PCM \\ U.S. Department of Energy, Headquarters \\ Idaho Chemical Processing Plant \\ Management Control System \\ National Environmental Policy Act \\ Operational Safety Requirement \\ Plant Safety Document \\ Process Control Manual \\ PUREX \\ Plutonium-Uranium Extraction (Plant) \\ RL \\ TRQ \\ TS/S \\ UNH \\ USQ \\ $\mathrm{UO}_{3}$ \\ WAC \\ WEC \\ WHC \\ WINCO \\ U.S. Department of Energy, Richland Operations Office \\ technical requirements \\ technical standards and specifications \\ uranyl nitrate hexahydrate \\ Unreviewed Safety Question \\ Uranium-Trioxide Plant \\ Washington Administrative Code \\ Westinghouse Electric Corporation \\ Westinghouse Hanford Company \\ Westinghouse Idaho Nuclear Company
}


WHC-EP-0693 Rev. 0

This page intentionally left blank. 
WHC-EP-0693 Rev. 0

\subsection{PURPOSE}

This study provides a comparison of the management, technical, compliance, and safety strategies for the phaseout of nuclear fuel reprocessing at the Idaho Chemical Processing PIant (ICPP) and deactivation of the Plutonium-Uranium Extraction (PUREX) Plant. The purpose of the study is to ensure that lessons-learned and future plans are shared to provide the maximum mutual benefit. 
WHC-EP-0693 Rev. 0

This page intentionally left blank. 


\subsection{MANAGEMENT APPROACH}

An integrated management approach has been established between Westinghouse Hanford Company (WHC) and Westinghouse Idaho Nuclear Company (WINCO). The integrated management approach will ensure that lessons-learned, future plans, and common technical activities are achieved for safe, efficient, and environmentally sound deactivation.

\subsection{PROJECT/PROGRAM PLANS}

A DOE-Headquarters (HQ) approved plan (October 1992) is in place and being used at ICPP. The PUREX/UO $\mathrm{O}_{3}$ Deactivation Project Management Plan was approved and submitted to the U.S. Department of Energy (DOE) Richland Operations Office (RL) on September 30, 1993. The basic content and purpose (to cease nuclear fuel processing) are essentially the same in the plans. However, because of physical facility configuration, some differences exist in the transition end points. These differences are presented and discussed in subsequent sections of this document.

The principle difference is the close integration of chemical processing facilities at ICPP with other ongoing activities as opposed to the isolated nature of PUREX. After the phaseout of reprocessing, the ICPP closely approximates PUREX in standby except that future maintenance activities at the ICPP will not be directed toward the restart of fuel reprocessing operations.

\subsection{ORGANIZATION}

The PUREX transition to deactivation organization is tailored to meet the guidelines for a project activity as provided in DOE Order 4700.1, Project Management System (DOE 1992). Several innovative features are included to ensure timely decision making, and stakeholder and expert overview involvement.

The PUREX $/ \mathrm{UO}_{3}$ Deactivation Project Management relationships are shown in Figure 1. Strong line authority is provided from the Deputy Assistant Secretary for Facility Transition and Management (EM-60) to HQ (EM-64), RL, and WHC project managers and operating personnel.

Within the PUREX organization, the three project managers are assisted by (1) a decision-making authority called the Project Team, (2) independent technical experts, (3) a transition advisory team (from the Red Team), which provides technical oversight, and (4) external stakeholders, who are involved at the RL site office level.

The ICPP organization follows a more conventional program (expense) structure as ICPP reprocessing facilities transition from defense production to environmental management. This more conventional approach is appropriate based on the close integration of phaseout (transition) activities with other ICPP site activities. 


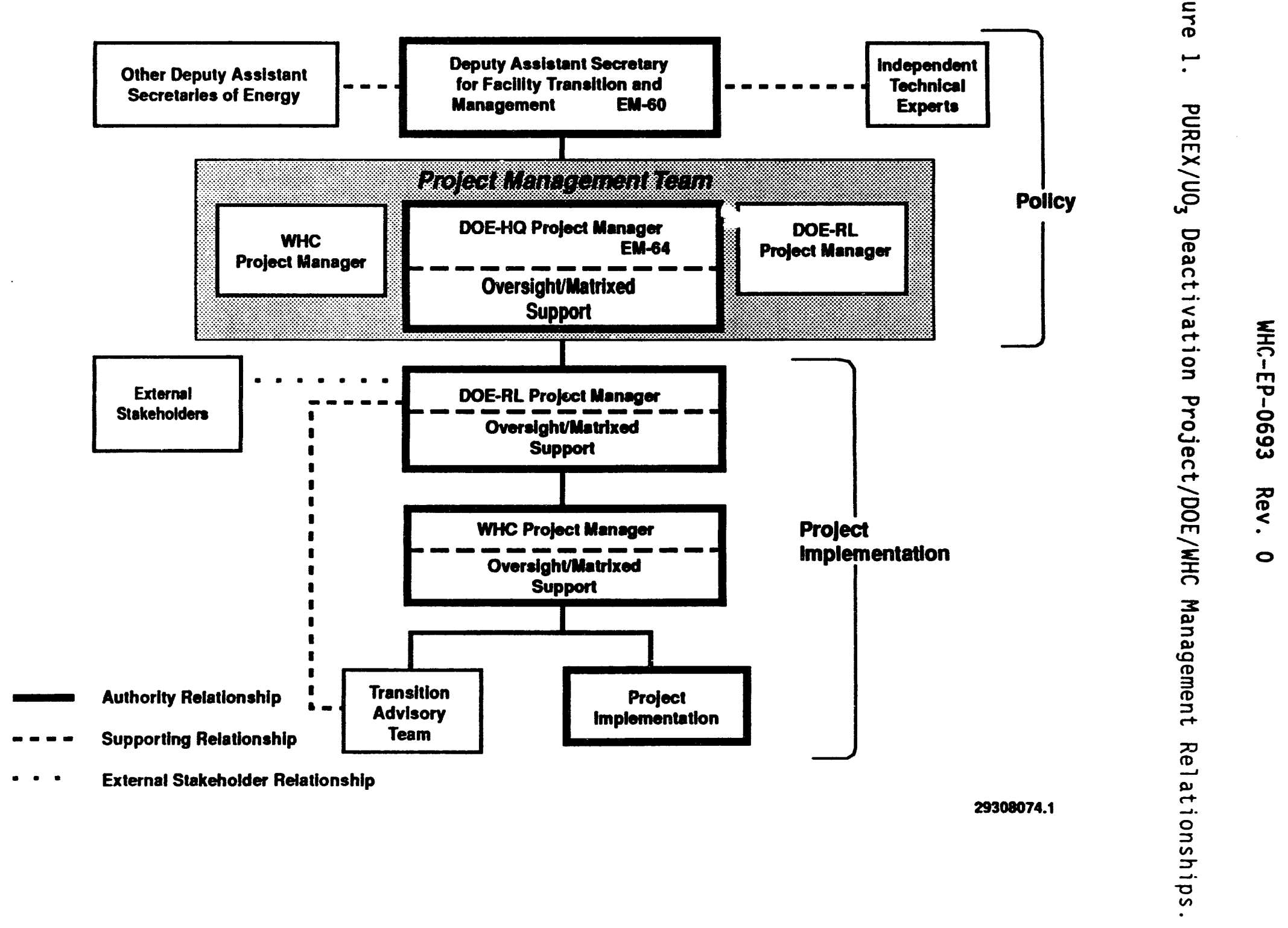


WINCO management is subdivided into nine departments under one president, who is the chief executive officer. The departments are arranged in a conventional organization. Line management in each department is responsible for applicable phaseout/transition activities as well as ongoing operations.

When phaseout activities are completed, WINCO will organize as appropriate to manage the rest of the transition process. The re-organization will provide for the management of future plant characterization, decontamination, and ultimate disposition of facilities in transition. Disposition may include reuse by DOE, release to non-DOE users, or decommissioning.

\subsection{PROJECT/PROGRAM CONTROL SYSTEM}

WHC and WINCO currently use a conventional management control system (MCS) consisting of cost accounts, monthly status reports, milestone reporting systems, and annual budgets.

The MCS implemented on the PUREX/UO 3 Deactivation Project uses the WHC MCS, documented in WHC-CM-2-5, Management Control System. The project MCS provides a uniform approach to be used throughout the project. The primary goal of this management system is to ensure planning and execution of this project in a manner that is technically sound, timely, and cost-effective. All planning is identified and correlated to the Project Summary Work Breakdown Structure, as shown in Figure 2.

The system focuses on establishing and controlling baselines at the overall project level and at the principal functional organization level. The summary project level baselines are managed by $\mathrm{RL}$.

Management reports provide timely, accurate data to provide the contractor Project Team and DOE management with current and projected conditions. Information contained in these reports is obtained from the same database that supports day-to-day management by the Project Team. A comparison of the two MCSs is provided in Table 1 . The type and number of reports used at both sites are similar. However, the management structures are different and different managers and organizations receive and use the reports.

\subsection{STAKEHOLDER INVOLVEMENT}

The extent of stakeholder involvement is based on regional interest and requirements. In general, the planning for stakeholder involvement for PUREX is similar to that for ICPP. WHC and WINCO are committed to fully communicating information to all interested individuals and groups. Table 2 summarizes the communication activities for the two companies. 


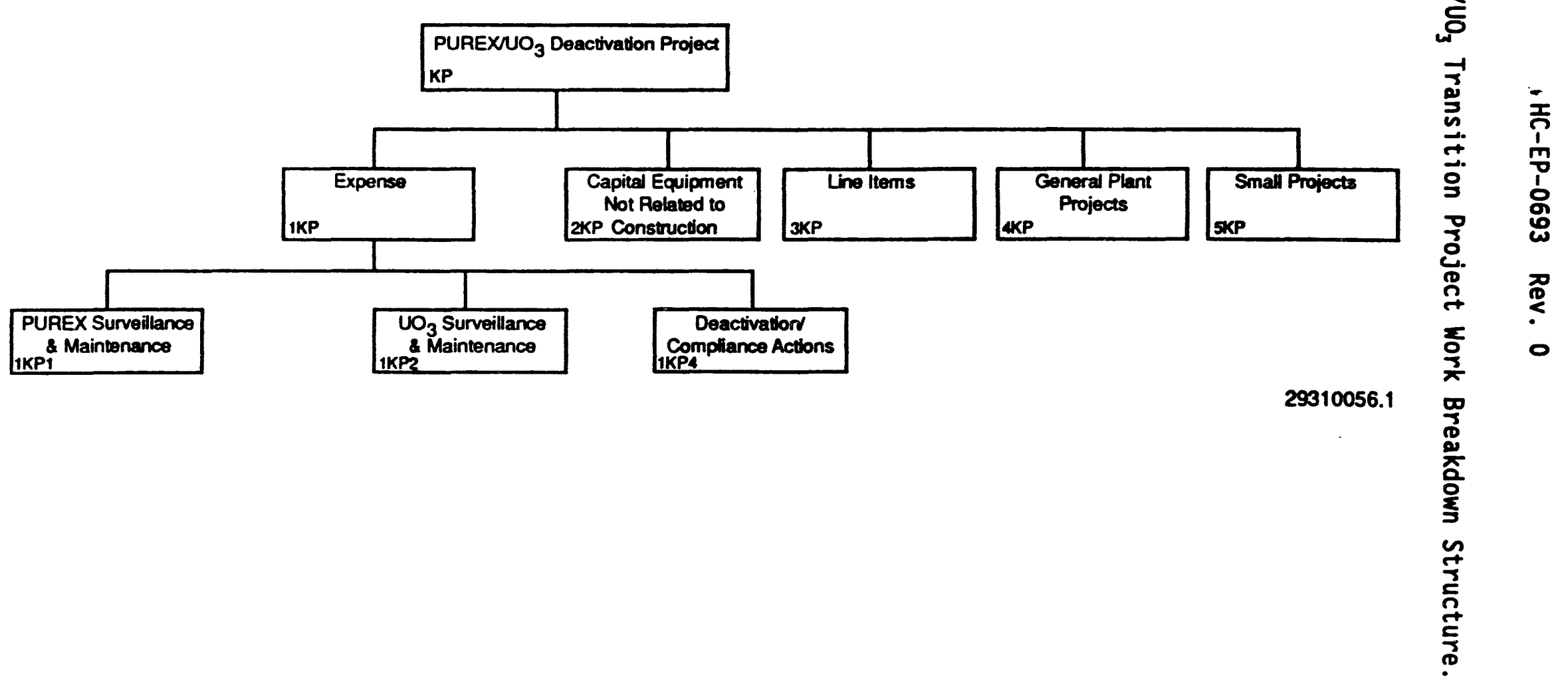


Table 1. A Comparison of Management Control Systems for PUREX and ICPP.

\begin{tabular}{|c|c|}
\hline PUREX & ICPP \\
\hline $\begin{array}{l}\text { Site Management System Report } \\
\text { (Monthly) } \\
\text { - Given to RL } \\
\text { - Deactivation status incorporated } \\
\text { - Provides data for HQ Progress } \\
\text { Tracking System }\end{array}$ & $\begin{array}{l}\text { Site Management System Report } \\
\text { (Monthly) } \\
\text { - Given to ID } \\
\text { - Phaseout status included } \\
\text { - Provides data for HQ Progress } \\
\text { Tracking System }\end{array}$ \\
\hline $\begin{array}{l}\text { Cost Performance Report (Monthly) } \\
\text { - To project manager } \\
\text { - Provides cost performance } \\
\text { - Problem/variance analysis } \\
\text { - Incorporated into the Site } \\
\text { Management System }\end{array}$ & $\begin{array}{l}\text { Cost Performance Report (Monthly) } \\
\text { - To Manager, Programs Cost Control } \\
\text { and Budget } \\
\text { - Provides cost performance } \\
\text { - Problem/variance analysis }\end{array}$ \\
\hline $\begin{array}{l}\text { Milestone Schedule Status Report } \\
\text { (Monthly) } \\
\text { - To project manager } \\
\text { - Baseline project schedule with } \\
\text { status } \\
\text { - Statused DOE milestone list } \\
\text { - Brief narrative of current } \\
\text { schedule position }\end{array}$ & $\begin{array}{l}\text { Milestone Schedule Status Report } \\
\text { (Monthly) } \\
\text { - To Manager, Planning Integration } \\
\text { - Baseline phaseout schedule with } \\
\text { status } \\
\text { - Statused DOE milestone list } \\
\text { - Brief narrative of current } \\
\text { schedule position }\end{array}$ \\
\hline & $\begin{array}{l}\text { DOE-ID/ICPP Operations Report } \\
\text { - Weekly phaseout status }\end{array}$ \\
\hline
\end{tabular}


Table 2. Stakeholder/Project Communication.

\begin{tabular}{|c|c|c|}
\hline Activity & Westinghouse Hanford Company & $\begin{array}{l}\text { Westinghouse Idaho Nuclear } \\
\text { Company }\end{array}$ \\
\hline Public/Legislative Involvement & $\begin{array}{l}\text { Tri-Party Agreement Quarterly } \\
\text { Tri-Party Agreement Monthly } \\
\text { Project and Unit Managers Meeting } \\
\text { Washington State Historic } \\
\text { Preservation Office Meetings } \\
\text { Environmental Restoration and } \\
\text { Advisory Committee Meetings } \\
\text { Site Specific Advisory Board } \\
\text { State and Tribal Working Group } \\
\text { Meetings } \\
\text { Project Workshops }\end{array}$ & $\begin{array}{l}\text { Eastern Idaho Business/Educators } \\
\text { Meetings } \\
\text { State Oversight Committee Weekly } \\
\text { Meetings } \\
\text { State EPA Meetings/Tours } \\
\text { Snake River Alliance } \\
\text { Meet ings/Tours } \\
\text { Shoshone/Bannock Working Group } \\
\text { Meetings } \\
\text { General Public Semiannual } \\
\text { Briefings and Workshops } \\
\text { INEL Reporter } \\
\text { INEL Outreach Offices }\end{array}$ \\
\hline News Media & $\begin{array}{l}\text { Regional Newspapers } \\
\text { Television News Media }\end{array}$ & $\begin{array}{l}\text { Regional Newspapers } \\
\text { Television News Media }\end{array}$ \\
\hline
\end{tabular}


Table 2. Stakeholder/Project Communication.

\begin{tabular}{|l|l|l|}
\hline \multicolumn{1}{|c|}{ Activity } & \multicolumn{1}{|c|}{ Westinghouse Hanford Company } & \multicolumn{1}{c|}{$\begin{array}{c}\text { Westinghouse Idaho Nuclear } \\
\text { Company }\end{array}$} \\
\hline Employee Information & $\begin{array}{l}\text { The Hanford Reach (weekly } \\
\text { newspaper) } \\
\text { Hanford Update (quarterly) } \\
\text { All-Managers Meetings (quarterly) } \\
\text { All-Employee Meetings (annually) } \\
\text { Total Quality Awareness Training } \\
\text { Management/Union Meetings } \\
\text { Employee Assistance Programi-annually) }\end{array}$ & $\begin{array}{l}\text { All-Employee Meetings (annually) } \\
\text { newspaper) } \\
\text { The Pulse (monthly) } \\
\text { Management Round Table Meetings } \\
\text { Total Quality Awareness Training } \\
\text { Joint Labor Management Quality } \\
\text { Committee } \\
\text { Employee Assistance Program } \\
\text { All-Employee Newsletter }\end{array}$ \\
\hline
\end{tabular}


The success of the ICPP and PUREX phaseout/transition depends on whether it is accepted by the organizations and groups who can impact the activities. The following is a list of these organizations and groups.

- Existing DOE, WHC, and WINCO organizational structures (e.g., the matrixed and support groups who have project concurrence or approval authority)

- Legislated authority structure (e.g., the Washington State Department of Ecology, the Defense Nuclear Facilities Safety Board, and the Idaho Department of Environmental Quality [DEQ])

- Public pressure generaced by public advocates, advisory groups, or public opinion.

The purpose of the activities outlined in the ICPP and PUREX deactivation plans is to accomplish the following actions.

- Establish a common information base from which interested parties can learn about the facilities, their current status, and the decisions that have been made and will be made as facility status evolves.

- Inform stakeholders about transition-to-deactivation alternatives, end point objectives, and the constraints, costs, and timetable associated with each of these.

- Facilitate the transfer of information, feedback, and verification as transition-to-deactivation alternatives are evaluated, selected, and implemented.

- Keep stakeholders apprised of the progress of the deactivation activities.

\subsection{APPROACH TO END-STATE DEFINITION}

The end-state of PUREX and ICPP fuel reprocessing facilities are significantly different. Parts of the ICPP processing facilities will remain active to support waste transfers, chemical makeup, and 1aboratory services. In contrast, PUREX will be unoccupied and locked with no active systems except limited ventilation and lighting.

\subsubsection{PUREX $/ \mathrm{UO}_{3}$ Deactivation Project End State}

The PUREX $/ \mathrm{UO}_{3} \mathrm{Plants}$ will be passively safe, environmentally secure, unoccupied, and locked. At PUREX, there will be no active systems or utilities within the confinement structures except for minimum canyon ventilation and lighting. A quarterly surveillance of the PUREX/UO $\mathrm{O}_{3} \mathrm{Pl}$ ants will be performed. 


\subsubsection{ICPP Phaseout End State}

There will be no active fuel processing at the ICPP at the completion of phaseout. Operations to support waste transfers, laboratory functions, and chemical makeup will continue in the same facilities to support ongoing missions. A comparison of key features with PUREX is shown in Table 3.

The facilities will be transitioned to a safe and stable shutdown condition. Fissile and hazardous materials will be removed, al though no specific attempt will be made to decontaminate equipment or processing cells to given contamination or radiation levels. Pipes and tanks will have been rinsed or flushed, and the facility's uranium content will be removed and accounted for. Maintenance needs for equipment with possible future uses will be identified. Characterization, defined as the data gathering and evaluations necessary for DOE to make decisions regarding decontamination, decommissioning, and future use, will be completed. Surveillance and maintenance activities will be performed until future disposition decisions are made.

Table 3. End-State Key Features Comparison.

\begin{tabular}{|l|l|}
\hline \multicolumn{1}{|c|}{$\mathrm{PUREX} \mathrm{UO}_{3}$} & \multicolumn{1}{|c|}{ ICPP } \\
\hline Fuel processing systems inactive & Fuel processing systems inactive \\
\hline Industrial security only & $\begin{array}{l}\text { Special nuclear material security } \\
\text { (nuclear fuel and final products } \\
\text { only) }\end{array}$ \\
\hline Analytical laboratory deactivated & Normal site laboratory support \\
\hline Office and facility space vacated & Office space for support operations \\
\hline No liquid effluents & $\begin{array}{l}\text { Limited liquid effluents for support } \\
\text { services }\end{array}$ \\
\hline $\begin{array}{l}\text { Utilities isolated (except limited } \\
\text { electrical and lighting) }\end{array}$ & $\begin{array}{l}\text { Normal utilities (except directly to } \\
\text { process cells and equipment) }\end{array}$ \\
\hline Limited canyon ventilation only & Normal ventilation services \\
\hline Canyon cranes shall be mothballed & Access systems active \\
\hline
\end{tabular}


WHC-EP-0693 Rev. 0

This page intentionally left blank. 


\subsection{FACILITY TECHNICAL COMPARISON}

The PUREX Plant (202-A Building), where the fuels are reprocessed, is a reinforced concrete structure that is $306 \mathrm{~m}(1,005 \mathrm{ft}) 10 \mathrm{ng}, 36 \mathrm{~m}$ (119 ft) wide at its maximum, and 30.5 (100 ft) high, with about $12 \mathrm{~m}(40 \mathrm{ft})$ of this height below grade. The building consists of three main structural components; (1) a thick-walled concrete canyon where the equipment for radioactive processing is contained (in cells, below grade); (2) the Pipe and operating (P\&O), Sample, and Storage galleries; and (3) a steel-and-transite annex that houses offices, process control rooms, laboratories, and the building services. The basic features and arrangement are shown in Figure 3 . The portion of the canyon below grade is subdivided into a row of process equipment cells paralleled by a ventilation air tunnel and pipe tunnel through which intercell solution transfers are made. The air tunnel exhausts the ventilation air from the cells to the main ventilation filters and stack.

A craneway for three gantry-type maintenance cranes runs nearly the full length of the canyon building, above the cells and pipe trench. The cranes are used to handle cell cover blocks, remotely remove and replace process cell equipment, and charge irradiated fuel into the dissolvers.

The galleries contain service piping to the cells, samplers for obtaining process samples, and electrical switchgear.

The service section next to the galleries consists of two separate annexes. The larger annex contains the maintenance ships, offices, lunchroom, locker room, radiation zone entry lobby, blower room, a switchgear room, compressor room, central control room, and the aqueous makeup area. The smaller annex contains the analytical laboratory, the headend control room, and a switchgear room.

Figure 4 is an aerial view of the PUREX Plant that shows the main processing building (202-A Building) and surrounding supporting facilities that will be deactivated. Figure 5 is the PUREX yard plan, which identifies major components of the PUREX/UO ${ }_{3}$ Deactivation Project. Excluded from the project scope are the PUREX Storage Tunnel Number 1 and Number 2.

All processing operations for converting uranyl nitrate hexahydrate (UNH) to $\mathrm{UO}_{3}$ are contained within two main structures. The 224-U Building contains a set process involving UNH concentration. The 224-UA Building contains a dry process, which involves converting $\mathrm{UNH}$ to $\mathrm{UO}_{3}$ powder. Buildings $224-\mathrm{U}$ and 224-UA are located in the 200 West Area.

The $\mathrm{UO}_{3}$ Plant supports the PUREX Plant by further processing uranium recovered from irradiated fuel elements. UNH from the PUREX PIant is converted to $\mathrm{UO}_{3}$ powder at the $\mathrm{UO}_{3} \mathrm{Plant}$. Functions at the $\mathrm{UO}_{3} \mathrm{Pl}$ ant that support $\mathrm{UNH}$ conversion to $\mathrm{UO}_{3}$ powder include the following.

- Receive, store, and concentrate UNH

- Recover nitric acid to reuse at the PUREX P1ant

- Package, store, and ship $\mathrm{UO}_{3}$ powder

- Dispose of waste and recover scrap. 
Figure 3. Plan Views of the PUREX Plant (202-A Building).

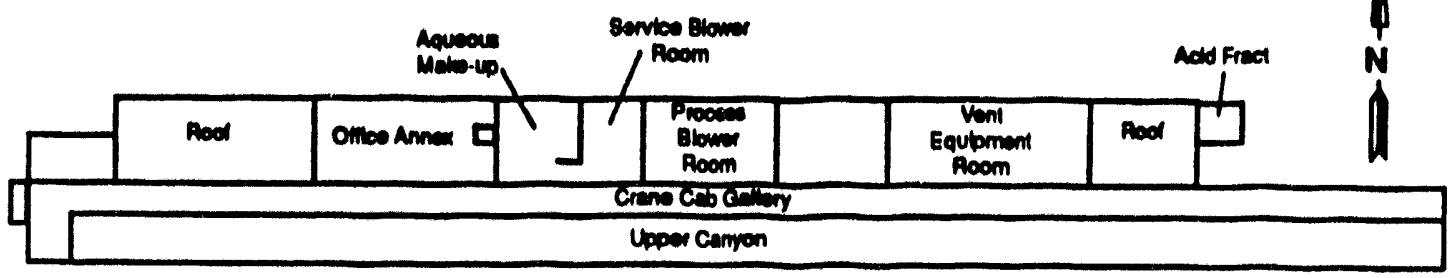

Plan - Crane Cab Gallery Level
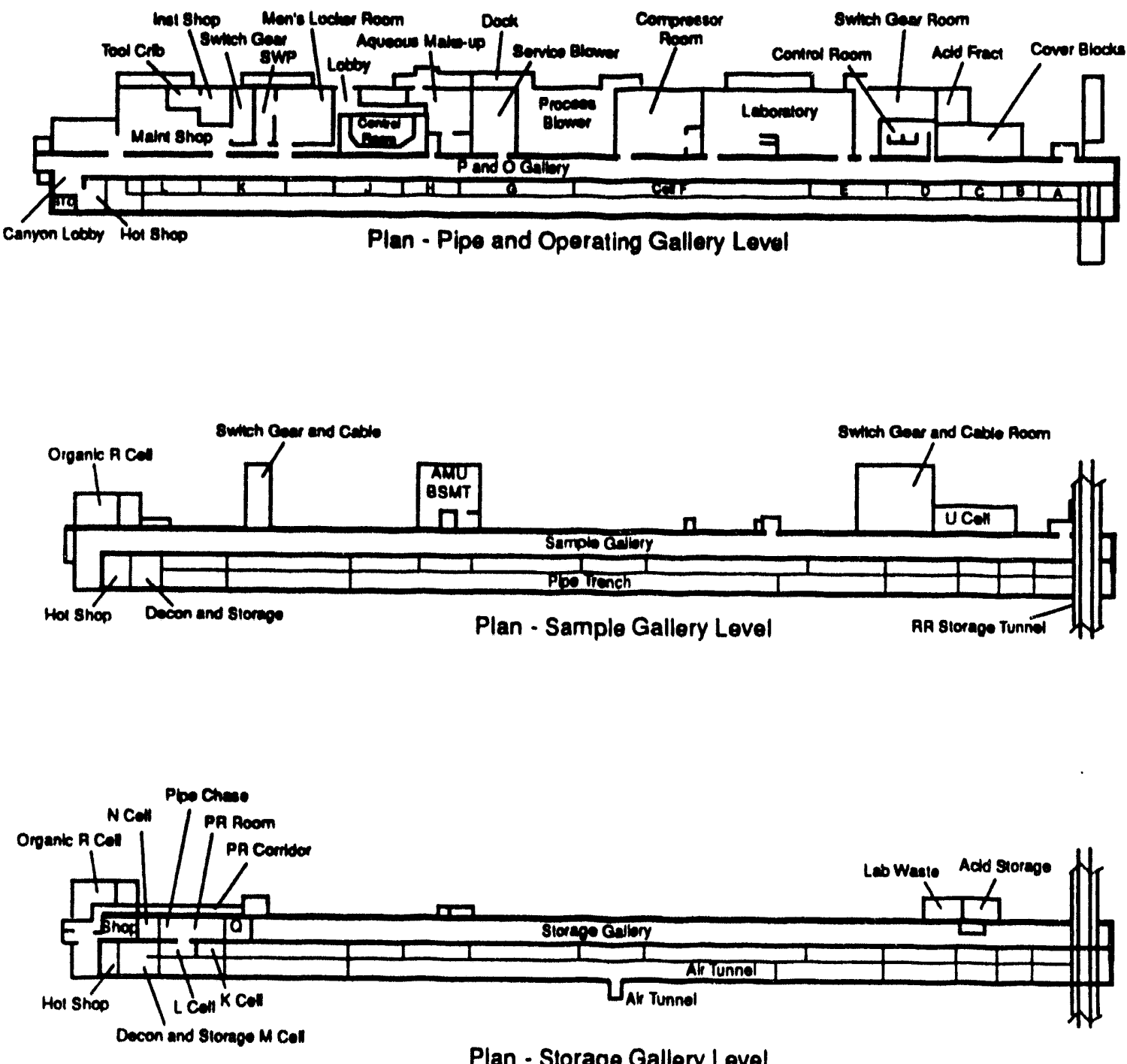

Plan - Storage Gallery Level 


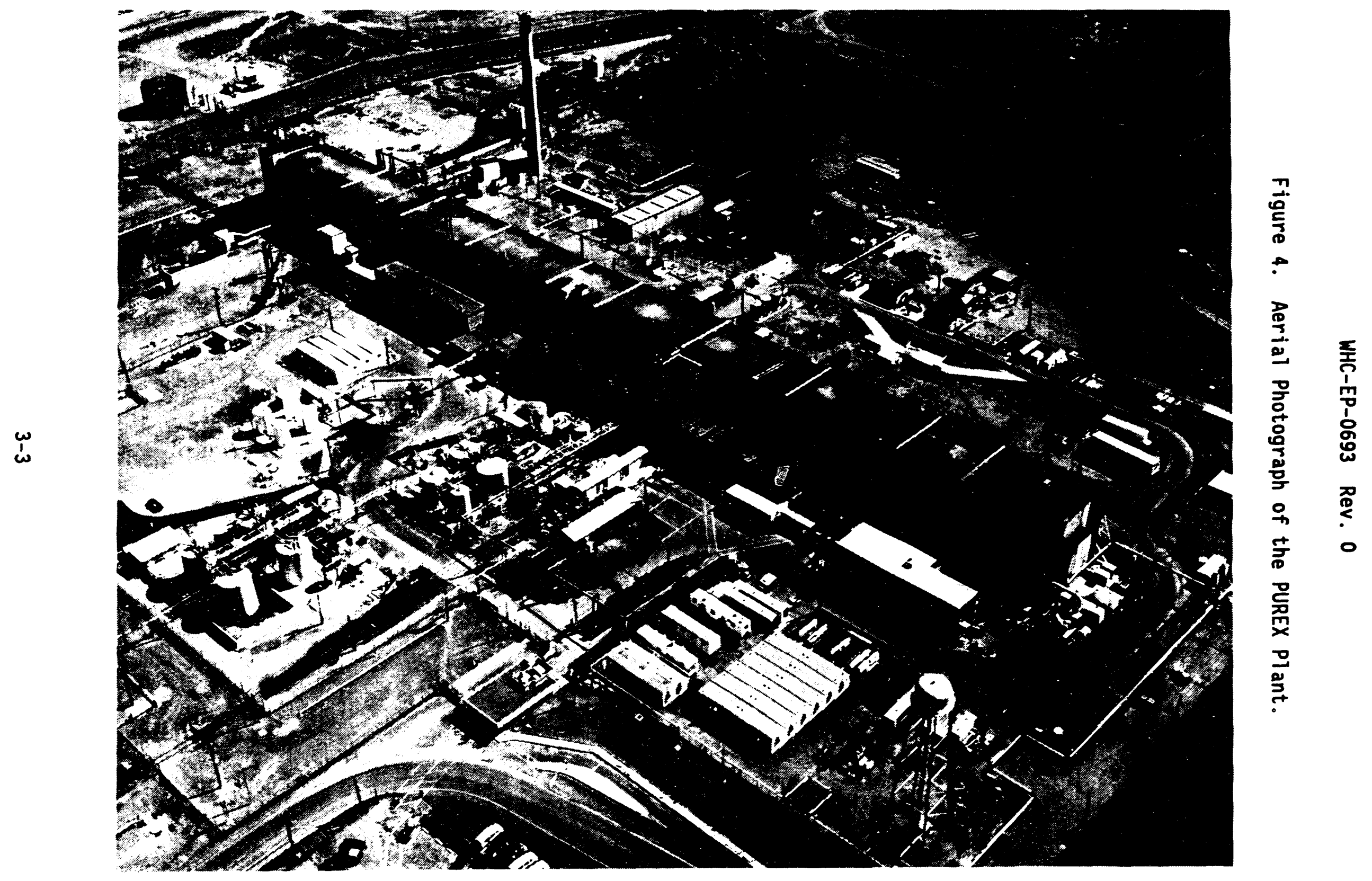




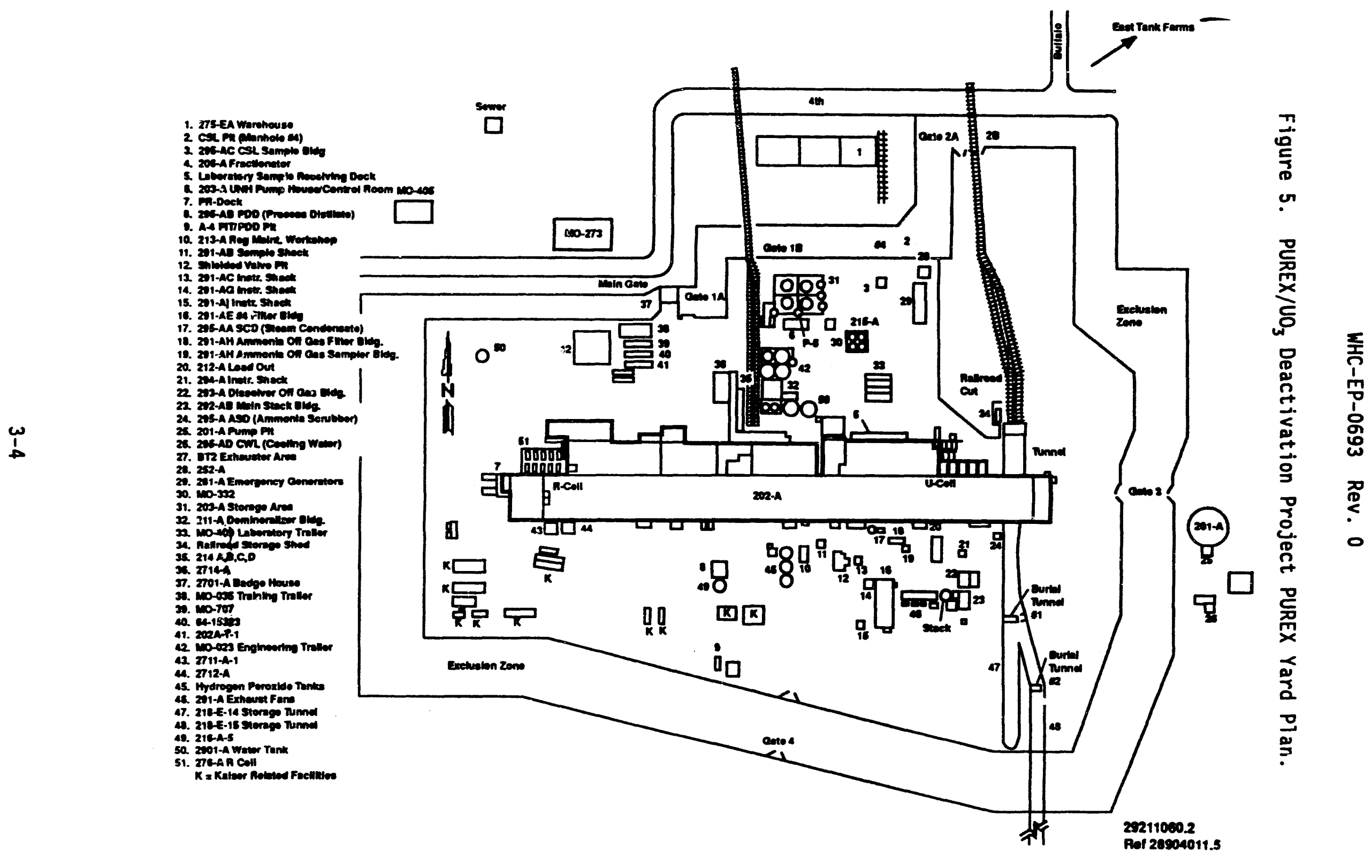


The 224-UA Building was built in 1956. The foundation is $23 \mathrm{~m}(75 \mathrm{ft})$ long and $20 \mathrm{~m}(67 \mathrm{ft})$ wide. The floor slab and footing is reinforced concrete $15 \mathrm{~cm}$ to $20 \mathrm{~cm}$ ( 6 in. to 8 in.) thick. Equipment footings and supports are reinforced concrete pier columns with steel "I" beam framing. Outside walls consists of insulated 18-gauge metallic coated steel panels.

The structure, comprising $1,113 \mathrm{~m}^{2}\left(11,982 \mathrm{ft}^{2}\right)$, is $60 \mathrm{~m}$ (197 ft) long, $18 \mathrm{~m}(60 \mathrm{ft})$ wide, and $18 \mathrm{~m}(60 \mathrm{ft}) \mathrm{tall}$. The building is divided lengthwise by a $30 \mathrm{~cm}$ ( 12 in.) -thick concrete shield wall into a gallery side and a canyon side. The gallery side is a three-story reinforced concrete frame structure with concrete floor and roof slabs. Exterior and interior infill walls are non-reinforced, $20 \mathrm{~cm}(8 \mathrm{in.})$ concrete blocks.

Figure 6 is an aerial photograph of the $\mathrm{UO}_{3}$ Plant that shows the main processing buildings (Buildings 224-U and 224-UA) and the surrounding support facilities to be deactivated. Figure 7 is the $\mathrm{UO}_{3}$ yard $\mathrm{pl}$ an that identifies major elements of the $\mathrm{UO}_{3} \mathrm{Pl}$ ant that support the $\mathrm{OO}_{3} \mathrm{Pl}$ ant and are part of the PUREX $/ \mathrm{UO}_{3}$ Deactivation Project.

The ICPP contains more than 100 facilities and support buildings located on approximately 200 acres in southeast Idaho. An aerial view of the site is provided in Figure 8. Current activities include storing spent and unirradiated fuel, managing waste, and developing and transferring advanced new technologies. The ICPP contains seven major processes/facilities once designated for use in part or wholly for nuclear fuels reprocessing:

- Fluorinel Dissolution Process (CPP-666)

- Custom Dissolution Process (CPP-627)

- Head-end Processes (CPP-640)

- Separations Facilities (CPP-601 and CPP-602 Denitrator)

- Rare Gas Plant (CPP-604)

- Fuel Processing Restoration Facility (CPP-691)

- Waste Calcining Facility (CPP-633).

A yard plan of the ICPP, which is shown in Figure 9, identifies the seven facility locations with hash marks.

The heart of reprocessing at ICPP is the uranium-extraction process, which is primarily contained in CPP-601. A floor plan of CPP-601 is shown in Figure 10. The process building contains 29 process cells, most of which are about $1.9 \mathrm{~m}^{2}\left(20 \mathrm{ft}^{2}\right)$ and $8.5 \mathrm{~m}(28 \mathrm{ft})$ deep, numerous corridors, and auxiliary cells that house equipment and controls. The bottom of each cell is lined with stainless steel, and most of the equipment is made of stainless steel. Most of the processing equipment in the building is located in heavily shielded cells and must be operated remotely. The entire plant was designed with a direct-contact philosophy, in that maintenance is performed by direct manual contact during periodic shutdowns after the cell and equipment are decontaminated to reduce radiation fields. 


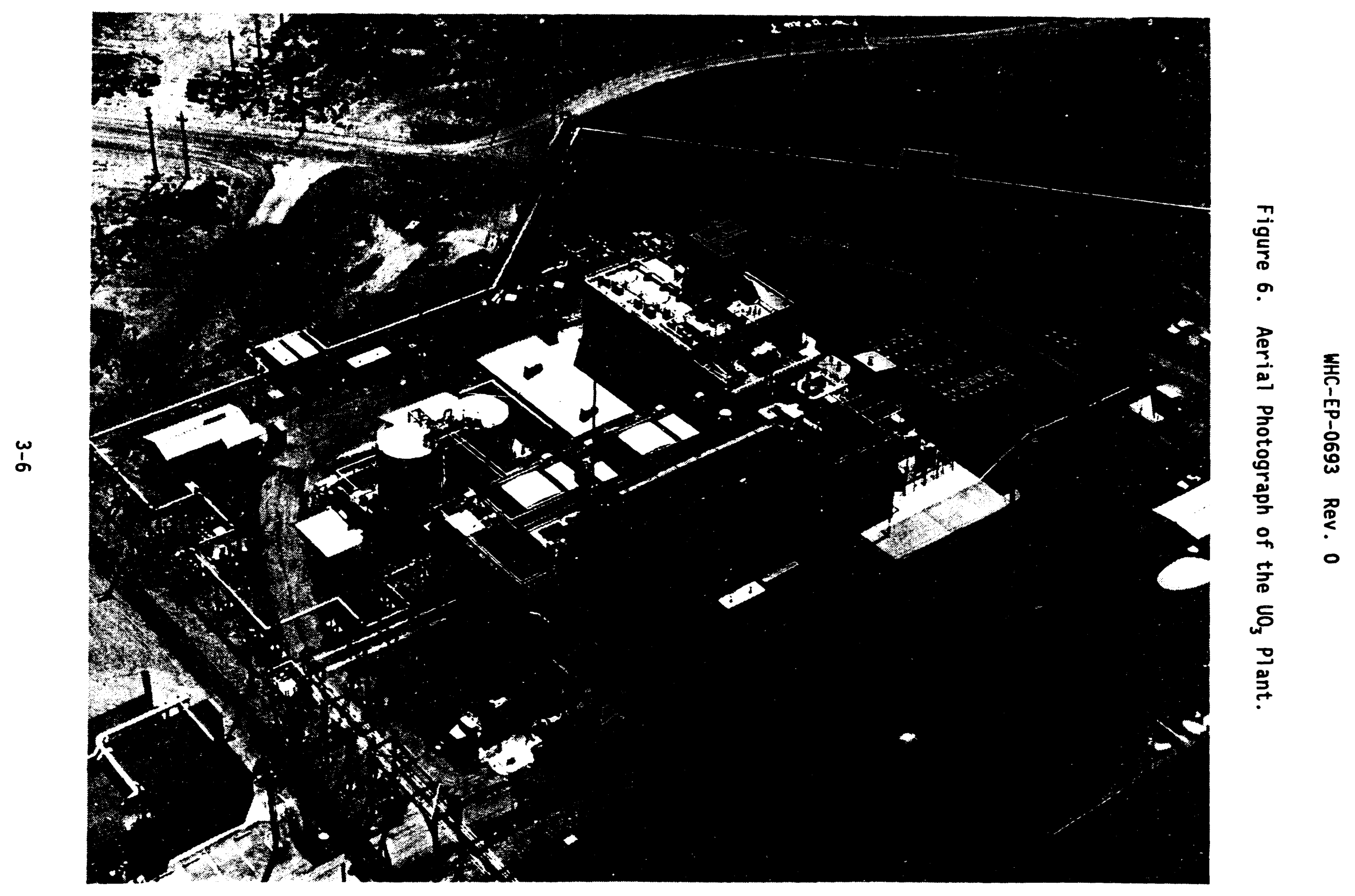


WHC-EP-0693 Rev. 0

Figure 7. PUREX $/ \mathrm{UO}_{3}$ Deactivation Project $-\mathrm{UO}_{3} \mathrm{Plant}$ Yard Plan.

Legend

1. 211-U Storage Tank Farm

2. Ma-722 Moblb Otiles

3. Ma-351 Mobils Otiles

4. MO-419 Mobils Otile

5. Mo-107 Mobllo Oritice

6. $224 \mathrm{U}$ Main Process Bullding

7. 224UA Caleiner Bullding

8. $272-U$ Maintonanco Facility

9. 203-U UNH Storage

Not shown on figure

10.207.U Rotention Basin

Areas Includod in Project Scopo

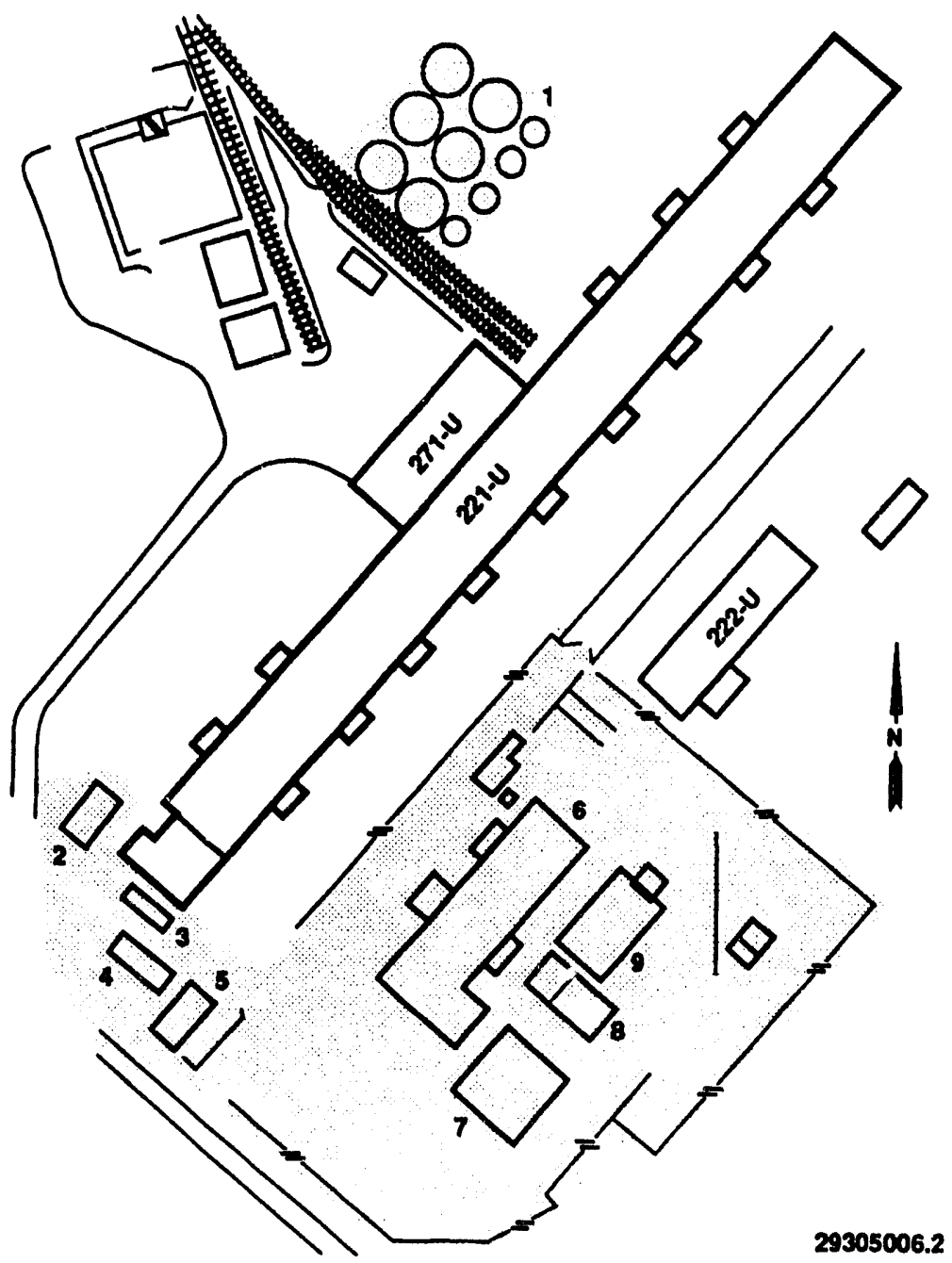




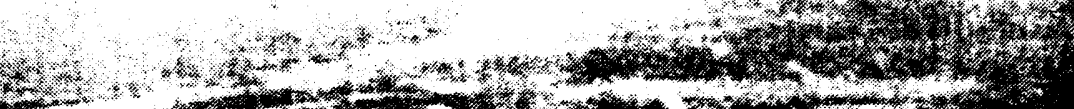

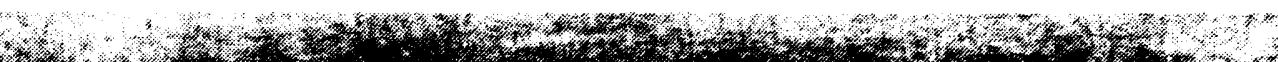

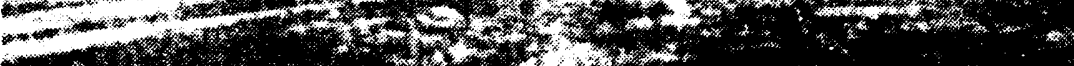
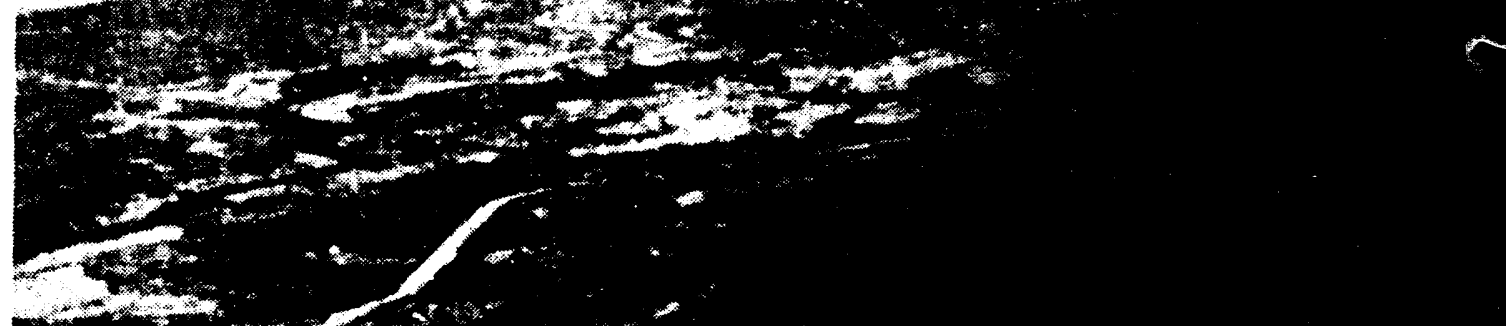

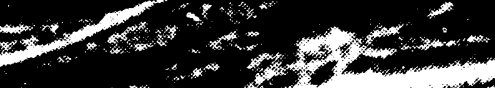

\section{$c^{2}+2=-2+2$}

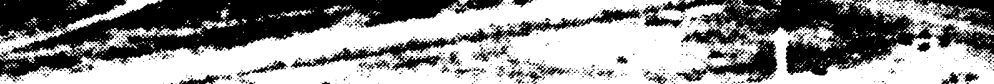

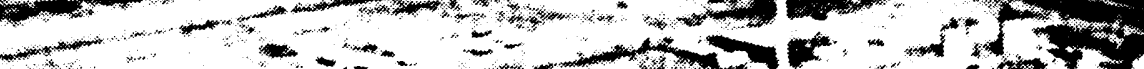

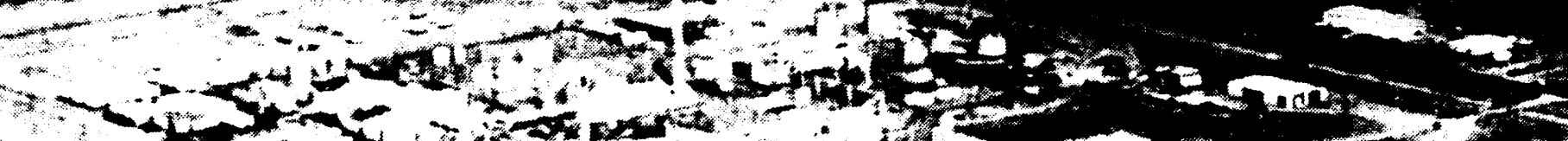

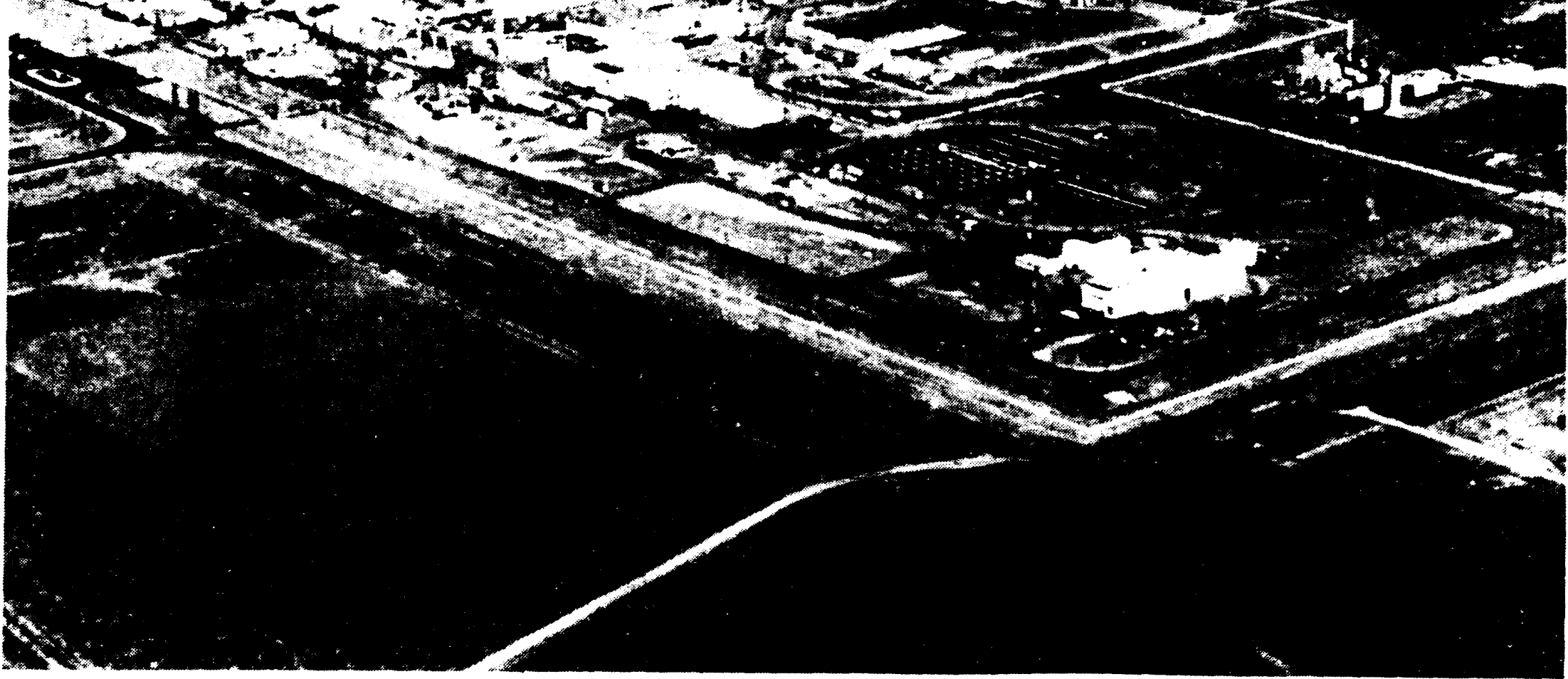


Figure 9. ICPP Yard Plan.

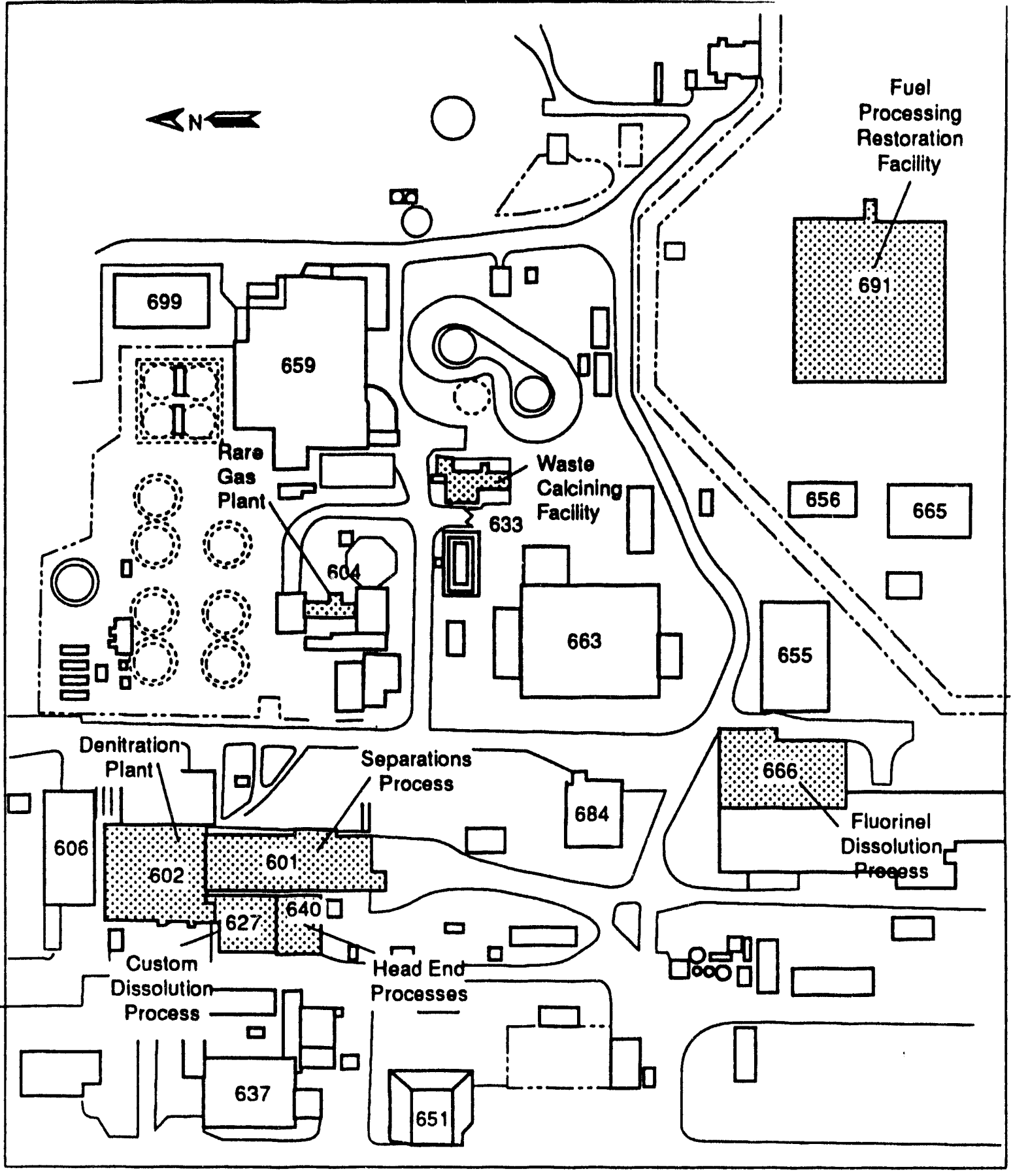


WHC-EP-0693 Rev. 0

Figure 10. Floor Plan View of ICPP Separations Facilities.

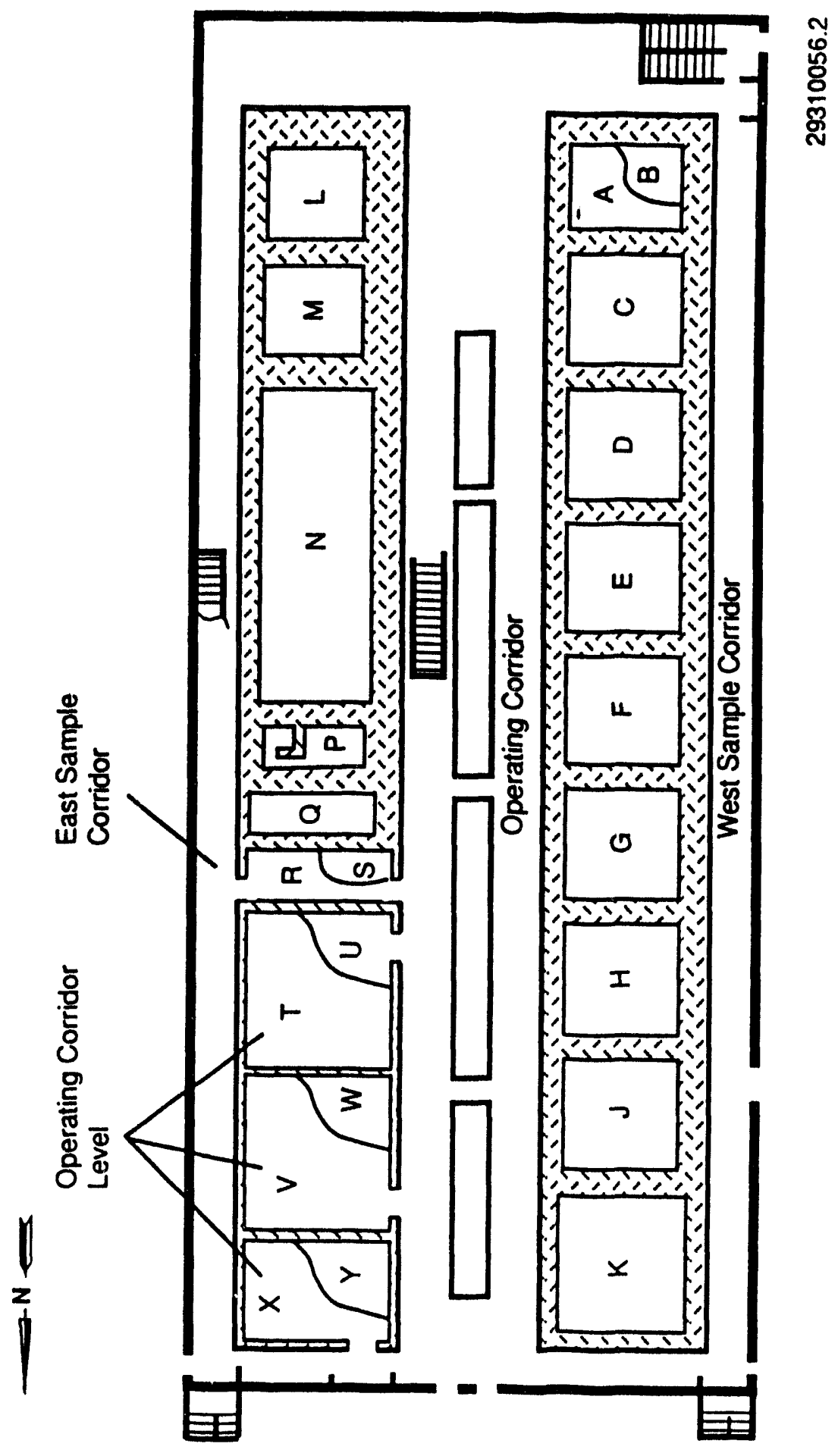


Functions of the CPP-601 Separations Facility include the following.

- Head-end dissolution of aluminum and zirconium fuel

- Solvent extraction (three cycles) of uranium from dissolved fuels

- Solvent recovery

- Inter-cycle storage of uranyl nitrate

- Denitration of uranyl nitrate to $\mathrm{UO}_{3}$.

Three of the buildings under transition contain four head-end processes for uranium extraction. Each contains one or more dissolution process for a different type of fuel. Each head-end process feeds the extraction process in CPP-601. The four head-end processes are as follows.

- Fluorinel dissolution process (FDP) - zirconium fuels

- ROVER dissolution process - graphite fuels

- Electrolytic dissolution process - stainless steel fuels

- Custom dissolution - small quantities of custom fuel.

Three additional facilities are designated for transition: the Waste Calcining Facility in CPP-633, the Rare Gas Plant in CPP-604, and the Fuel Processing Restoration Facility in CPP-691. Construction on the Fuel Processing Restoration Facility is not complete. The original purpose of each facility is as follows.

- The Waste Calcining Facility calcined high-level liquid waste from the tank farm to produce a granular stable waste form.

- The Rare Gas Plant recovered krypton and xenon gases from aluminum and zirconium fuel dissolution off gases.

- The Fuel Processing Restoration Facility was designed to replace the fuel separations systems currently contained in CPP-601.

A comparison of PUREX and the ICPP reveals several similarities and differences. Both facilities were used to separate and recover fissile material from expended fuel cells using liquid-liquid extraction through a series of columns. However, PUREX was designed to recover uranium and plutonium in production quantities while the ICPP reprocessing facilities were designed to recover highly enriched uranium from a wide variety of fuels. This difference explains why PUREX is larger and designed as a canyon; whereas, the ICPP is smaller and designed around a cell concept. For a technical comparison of unit operations and pertinent functions of ICPP/PUREX, refer to Table 4.

\subsection{OPERATIONAL TECHNICAL COMPARISON}

Many similarities exist between ICPP and PUREX $/ \mathrm{UO}_{3}$ processes and technical principles. Table 4 provides an overall comparison of fuel, unit operations, radiation contamination levels, utilities status (at completion of 
Table 4. Technical Comparison.

\begin{tabular}{|c|c|c|}
\hline \multirow{5}{*}{$\begin{array}{l}\boldsymbol{\omega} \\
\underset{\sim}{\sim}\end{array}$} & \multicolumn{2}{|c|}{ FUEL } \\
\hline & PUREX & ICPP \\
\hline & $\begin{array}{l}\text { - Composition range } \\
-0.72 U^{235} \text { to } 2.1 \% U^{235} \text { early) } \\
0.94 \% U^{235} \text { to } 1.25 \% U^{235} \text { (recent) } \\
\text { Cladding } \\
\text { - Zirconium ( } \mathrm{N} \text { Reactor) } \\
\text { - Aluminum (early reactors) }\end{array}$ & $\begin{array}{l}\text { - Composition range } \\
\text { - Highly enriched } U^{235} \\
\text { (> } 50 \% \text { typically) } \\
\text { - Cladding } \\
\text { - Aluminum } \\
\text { - Zirconium } \\
\text { - Stainless steel } \\
\text { - Graphite } \\
\text { - Exotics (i.e., ceramics) }\end{array}$ \\
\hline & UNIT OPERATI & S - DISSOLVERS \\
\hline & $\begin{array}{l}\text { - } 3 \text { Identical dissolvers } \\
\text { - Annular } \\
\left(H=24^{\prime}, 00=10^{\prime}\right) \\
- \text { Zirflex process } \\
\text { - } 10 \text { to } 11 \text { metric tons per charge per } \\
\text { dissolver } \\
\text { - Capacity } \\
\text { - } 10 \text { to } 30 \mathrm{MTU} / \text { day }\end{array}$ & $\begin{array}{l}\text { - FDP: } 3 \text { identical dissolvers } \\
-\quad\left(H=17^{\prime}, 0 D=3^{\prime}\right) \\
- \text { Flourinel dissolution process } \\
-<1 \text { Metric ton per Charge } \\
\text { - G-Cell (aluminum) } \\
\text { - Electrolytic (SS) } \\
\text { - Rover (graphite) } \\
\text { - Custom (exotics) } \\
\text { - Capacity < } 1 \text { MTU/day) }\end{array}$ \\
\hline
\end{tabular}


Table 4. Technical Comparison.

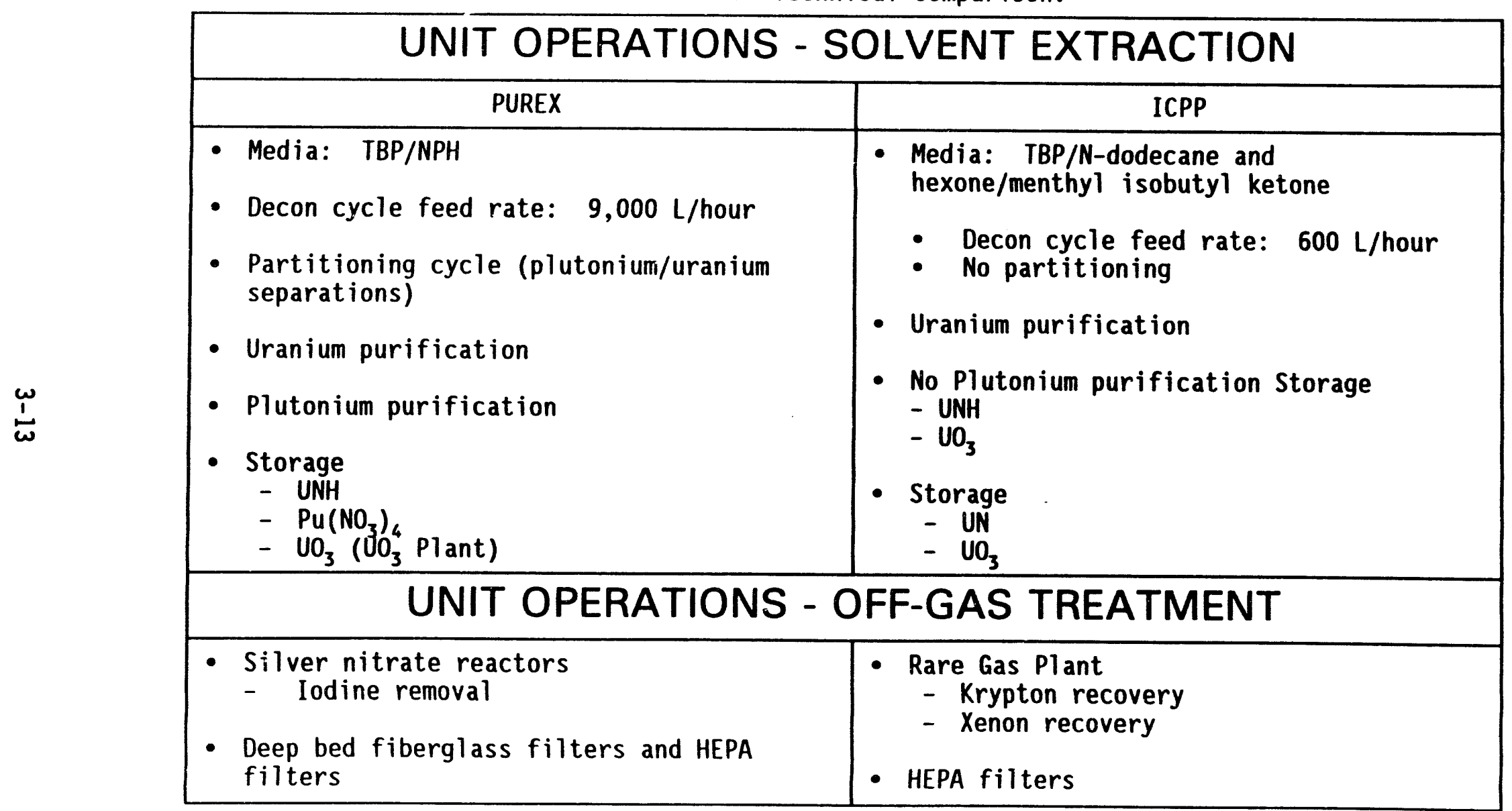


Table 4. Technical Comparison.

\begin{tabular}{|c|c|}
\hline \multicolumn{2}{|c|}{ EVAPORATORS/CONCENTRATORS AND TANKS } \\
\hline PUREX & ICPP \\
\hline $\begin{array}{l}\text { - Concentrators } \\
-5 \text { Large } \\
\text { - Average concentrator } \\
\text { - Height }=30^{\prime} \\
\text { - Reboiler } 00=54^{\prime \prime} \\
\text { - Total diameter: } 25^{\prime} \\
\text { - Operating volume: } \quad 3,500 \mathrm{Gal} \\
\text { - Tanks } \\
\text { - Several hundred } \\
\text { - } 1.5 \text { to } 15,000 \text { gal } \\
\text { - Standard: } 5,000 \text { gal }\end{array}$ & $\begin{array}{l}\text { - Evaporators } \\
-5 \text { Small, varied } \\
\text { - Largest evaporator } \\
\text { - Height }=15^{\prime} \\
\text { - ID }=5 \\
\text { - Steam chest diameter: } 7^{\prime} \\
\text { - Operating volume: } 20 \mathrm{Gal} \\
\text { - Tanks } \\
\text { - Several hundred } \\
\text { - Largest volume: } 4,500 \text { gal } \\
\text { - Most } 20 \text { to } 200 \text { gal range (criticality } \\
\text { considerations) }\end{array}$ \\
\hline \multicolumn{2}{|c|}{ UNIT OPERATIONS - DENITRATION } \\
\hline PUREX & ICPP \\
\hline $\begin{array}{l}\text { - } \mathrm{UO}_{3} \mathrm{Plant} \\
\text { - Design throughput - } 34.7 \mathrm{MTU} / \text { day } \\
\text { - Continuous rotary calcining } \\
\text { - PUREX } \mathrm{Pl} \text { lant } \\
\text { - } \mathrm{PUO}_{2} \text { weapons grade } \\
\text { - } \mathrm{PUO}_{2} \text { fuels grade } \\
\text { - Dual rotary calciners } \\
\text { - } 1 \mathrm{Kg} / \text { hour }\end{array}$ & $\begin{array}{l}\text { - UNH Denitrator (CPP-602) } \\
<1 \text { MTU/day } \\
\text { - Throughput - }-4 \mathrm{~L} / \text { hour } \\
\text { - Fluidized bed }\end{array}$ \\
\hline
\end{tabular}


Tehle 4. Technical Comparison.

\begin{tabular}{|c|c|}
\hline \multicolumn{2}{|c|}{ RADIATION/CONTAMINATION LEVELS } \\
\hline PUREX & ICPP \\
\hline $\begin{array}{l}\text { - Varied (alpha, beta, gamma) } \\
\text { - Remote decontamination } \\
\text { - Concrete cells } \\
\text { - Very limited access } \\
\text { - Dunnage: carbon steel } \\
\text { - } 0.3-300 \mathrm{R} / \mathrm{hr}\end{array}$ & $\begin{array}{l}\text { - Varied (alpha, beta, gamma) } \\
\text { - Hands-on decontamination (external } \\
\text { surfaces only) } \\
\text { - Stainless steel floors/liners } \\
\text { - Doors/hatches } \\
\text { - Dunnage: stainless steel } \\
\text { - } 0 \text { - } 0.4 \mathrm{R} / \mathrm{hr} \text { (with localized fields up } \\
\text { to } 100 \mathrm{R} / \mathrm{hour} \text { ) }\end{array}$ \\
\hline \multicolumn{2}{|c|}{ UTILITIES* } \\
\hline PUREX & ICPP \\
\hline $\begin{array}{l}\text { - Steam - none } \\
\text { - Water - none } \\
\text { - Power - limited } \\
\text { - HVAC - limited }\end{array}$ & $\begin{array}{l}\text { - Steam - minimal change } \\
\text { - Hater - minimal change } \\
\text { - Power - minimal change } \\
\text { - HVAC - minimal change }\end{array}$ \\
\hline
\end{tabular}


Table 4. Technical Comparison.

\begin{tabular}{|c|c|}
\hline \multicolumn{2}{|c|}{ UNIT OPERATIONS - SUPPORT SYSTEMS } \\
\hline PUREX & ICPP \\
\hline 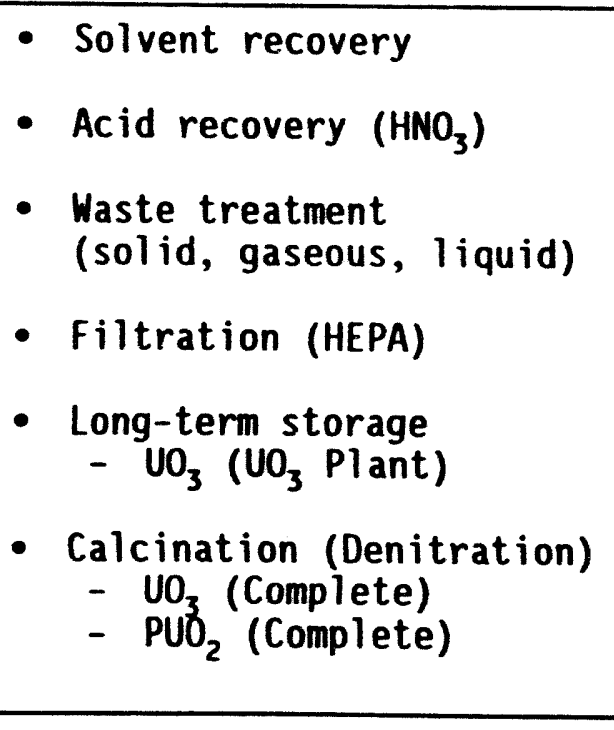 & 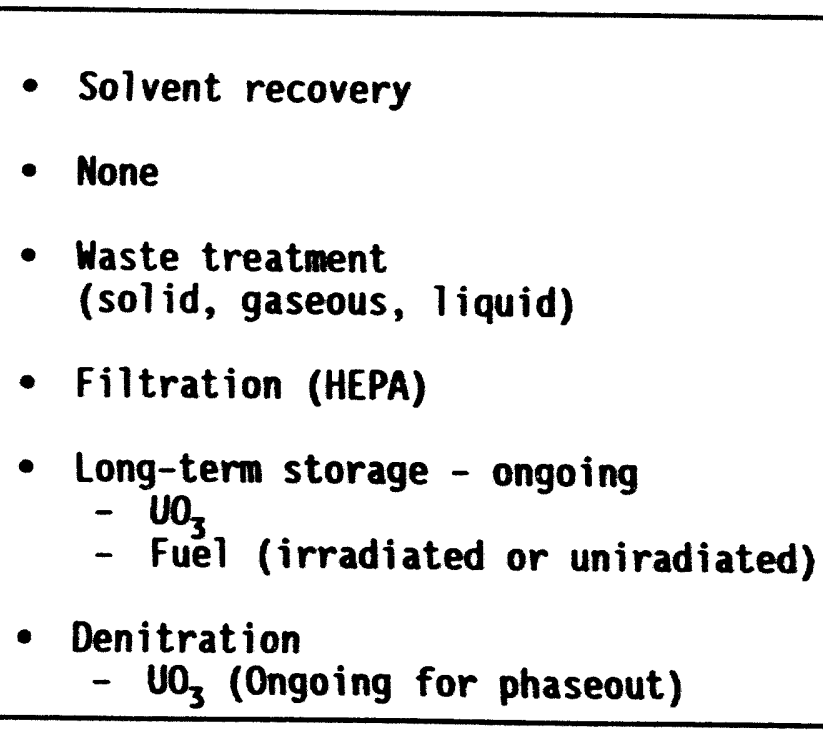 \\
\hline
\end{tabular}


to deactivation phaseout) and support systems for the two sites. The following are key issues relative to the current status of ICPP and PUREX $/ U O^{3}$.

- PUREX/UO 3 calcination is complete.

- ICPP (in phaseout) will complete denitration activities.

- PUREX/ $\mathrm{UO}_{3}$ utilities will be limited at the conclusion of deactivation.

- ICPP utilities will change minimally at the conclusion of phaseout.

- PUREX/UO $\mathrm{O}_{3}$ will be secured using the best industrial safety practices with no routine occupancy.

- ICPP will require security in fuel and $\mathrm{UO}_{3}$ storage areas.

- ICPP phaseout facilities will be occupied by personnel.

- PUREX will use quarterly safety surveillance.

- ICPP separations facilities will have limited changes in surveillance status.

\subsection{POSSIBLE FUTURE USE}

There are no anticipated future uses for PUREX $/ \mathrm{UO}_{3}$ and the plants are being deactivated in preparation for decontamination and decommissioning. ICPP is being evaluated and characterized for possible future uses or for decontamination and decommissioning.

The development groups at WINCO will need additional space for nonradioactive component testing by fiscal year 1995. By fiscal year 2000 , space will be needed for integrated pilot-plant tests of new processes. These development activities will require more space than is currently available. There are plans to construct a multifunction pilot plant facility or a process demonstration facility to provide areas for integrated testing. Process demonstrations might be placed in one of the transition facilities such as the Fuel Processing Restoration Building. One or more of the integrated pilot plants may eventually be converted to a radioactive production process. Placement in a transition facility would eliminate the need to construct a new production facility. After the technology is proven, process operations could begin years sooner than scheduled, and facility costs would be greatly reduced.

Although most of the development activities will be performed using nonradioactive simulations, the technology must be verified with radioactive feed (e.g., using calcine, tank farm waste, or irradiated fuel). Radioactive cells, which may be required as soon as fiscal year 1996, could be located in existing facilities at the ICPP (e.g., the FDP cell or multicurie cell). 
WHC-EP-0693 ReV. 0

Although fuel reprocessing activities will end, analytical chemistry supports several ICPP activities and will remain an important organization as the mission changes. Analyses will be required for (i) facility characterizations during transition, (2) samples generated from waste processing operations, and (3) development work from the applied technology development programs. Analytical services will be required on a regular basis to support all of these operations. 


\subsection{COMPLIANCE STRATEGIES}

WHC and WINCO have similar approaches to deactivation and phaseout. The transition facilities are in compliance with the National Environmental Policy Act (NEPA) for their operation. Flushing activities that occur during phaseout are considered operational activities by DOE Order 5820.2A, Radioactive Waste Management. As such, they do not require additional NEPA documentation because these activities do not include significant physical modifications.

Some specific activities at both sites may fall outside the scope of existing documentation. Additionally, new NEPA documentation may be required following deactivation and phaseout. Transition facilities at the ICPP will be included in the 1995 site-wide Environmental Impact Statement. Final disposition of PUREX will be addressed by the Hanford Site Remedial Action Environmental Impact Statement and the final selection of 1 and use for Hanford Site areas. It is the intent of WHC and WINCO to meet all applicable state and federal requirements. Where issues are raised, both sites will prepare and reach agreement on an appropriate approach to compliance. 
WHC-EP-0693 Rev. 0

This page intentionally left blank. 
WHC-EP-0693 Rev. 0

\subsection{SAFETY DOCUMENTATION STRATEGY}

ICPP and PUREX are consistent in applying safety documentation for transition activities. Both are using previously prepared operational safety analyses to describe the facility safety scope. Specific variations are described in the following subsections. The goal of the project is to provide safety assurance while avoiding unnecessary and costly reevaluations.

\subsection{CURRENT FINAL SAFETY ANALYSIS REPORT STATUS}

The following documents contain operational safety requirement (OSR) information for PUREX.

- WHC-SD-HS-SAR-001, PUREX Plant Final Safety Analysis Report, (FSAR). Chapter 11 of the FSAR was written for an operating plant and contains 132 OSRs in the form of 23 safety boundaries or conditions and 109 control features. Safety boundaries provide specific values and technical requirements while safety conditions define requirements but are not directly measurable, and control features state what is controlled but do not list specific values or limits.

- WHC-CM-5-24, PUREX Process Control Manual (PCM). This document implements Chapter 11 safety boundaries/conditions and control features through a total of 186 control feature requirements as limiting conditions for operation, limiting control settings, administrative requirements, and surveillance requirements.

- WHC-SD-CP-0SR-006, Applicability of PUREX Operational Safety Requirements During Shutdown/Standby, (Applicability Document). This document evaluated the PCM requirements to determine which control feature requirements are applicable when PUREX is in a shutdown/standby mode. The purpose of the evaluation was to make it possible to better use the plant resources by eliminating unneeded instrument calibrations while maintaining the plant within the constraints of the current safety scope.

- WHC-SD-CP-RD-020, Application of Standardized Operational Safety Requirement Criteria to PUREX Operational Safety Requirements, (Split Report). Applicability of existing OSRs to standby conditions was evaluated using Draft DOE Order 5480.23, The Crosswalk Documentation and screening criteria.

The OSRs, as indicated in the section applicability statements, were written for an operating plant. The applicability statements in the PCM will be enhanced and expanded to cover the current plant status, thus reducing the number of OSRs requiring surveillance during deactivation. This action will release plant resources that can then be applied directly to completing defined tasks. 
The PCM will be reissued as a supporting document and will include the tables that are in the current applicability document. The reissued PCM will be maintained current to provide clear directions for implementing in facility procedures and tracking systems. The split report will be used as a reference document that supplies the basis for the revised applicability statements. Applicable OSRs will be identified by exception and flagged as necessary.

The current PCM requires only simple and easily understood revisions to a minimum number of documents, retains the current PCM format, which is familiar to Operations supervision, and eliminates the need to go through two document control systems. Applicability statements are common elements of commercial nuclear facility SARs and allow flexibility in applying the OSRs based on the facility operating mode.

As one of the conditions for transfer of the facility to decontamination and decommissioning, the PUREX Plant SAR will be reviewed and updated for deactivation/shutdown status in accordance with applicable WHC management requirements and procedures. Because PUREX will be a low-hazard (category 3 ) facility at that time, the effort will be directed primarily at updating the description of the physical plant.

The ICCP Final Safety Analysis Report contains technical standards and specifications (TS/S) and technical requirements (TRQ) for ICPP.

- ICPP Final Safety Analysis Report. Thirty-nine individual FSARs apply to facilities/processes that are in transition. The FSARs are compiled in the Plant Safety Document (PSD). As new systems or facilities were added to the ICPP, FSARs were prepared and added to the PSD.

The existing ICPP FSAR, Piant Safety Document, and the Technical Specifications/Standards describe the safety scope envelope for cleanout operations and will not require rewrite for phaseout, except for selective modifications. They are written to provide (1) successively larger margins to the safety envelope to prevent safety limits from being exceeded, (2) limiting conditions for operation, and (3) limiting control settings. After phaseout, the FSAR and implementing documents will be revised to reflect the shutdown status of processes and equipment.

\subsection{SAFETY DOCUMENTATION FOR TRANSITION}

Figure 12 shows the transition unreviewed safety question (USQ) process used by PUREX and ICPP as a safety strategy for transition and phaseout activities. In accordance with DOE Order 5480.21, Unreviewed Safety Questions, the USQ Screening process is used to cover phaseout/deactivation tasks. The USQ process provides early identification of tasks that may require additional safety evaluation and analysis. The facility administrative manuals provide the specific requirements for implementation of DOE Order 5480.21. 


\subsection{KEY RISKS AND HAZARDS}

The PUREX issues relative to residual organics were reviewed by the TOMSK-1 lessons-learned review team. The team's conclusions are as follows.

- The PUREX Plant SAR considers only the operational mode for safety scope definition.

- The PUREX Plant is shutdown as far as processing is concerned and the solvent isolated in two tanks.

- The steam and acid lines are blanked.

- The only concern is mixing for sampling and temperature monitoring.

- The PUREX Plant solvent storage tanks are equipped with mixers and temperature monitoring.

- No unacceptable risk exists because of PUREX solvent.

There may be safety issues related to disposing metal solution at PUREX, depending on the method selected for removal. At the present time, the metal solutions are isolated in two tanks.

Once the method for removal from the plant is selected, the process outlined in Section 5.2 will be used (safety documentation for one-time activities) to evaluate solution removal.

The remaining risks and hazards for PUREX and $\mathrm{UO}_{3}$ are typical industrial scenarios relative to a nuclear type facility. All activities are to be screened according to Section 5.2. There are risks and hazards (as with any activity) but appropriate controls and reviews are in place to minimize safety concerns for the workers, the environment, and the public.

At the ICPP, issues relative to the TOMSK-7 incident in Siberia were presented by a member of the review team that visited the TOMSK-7 facility. 
Figure 11. Transition USQ Process.

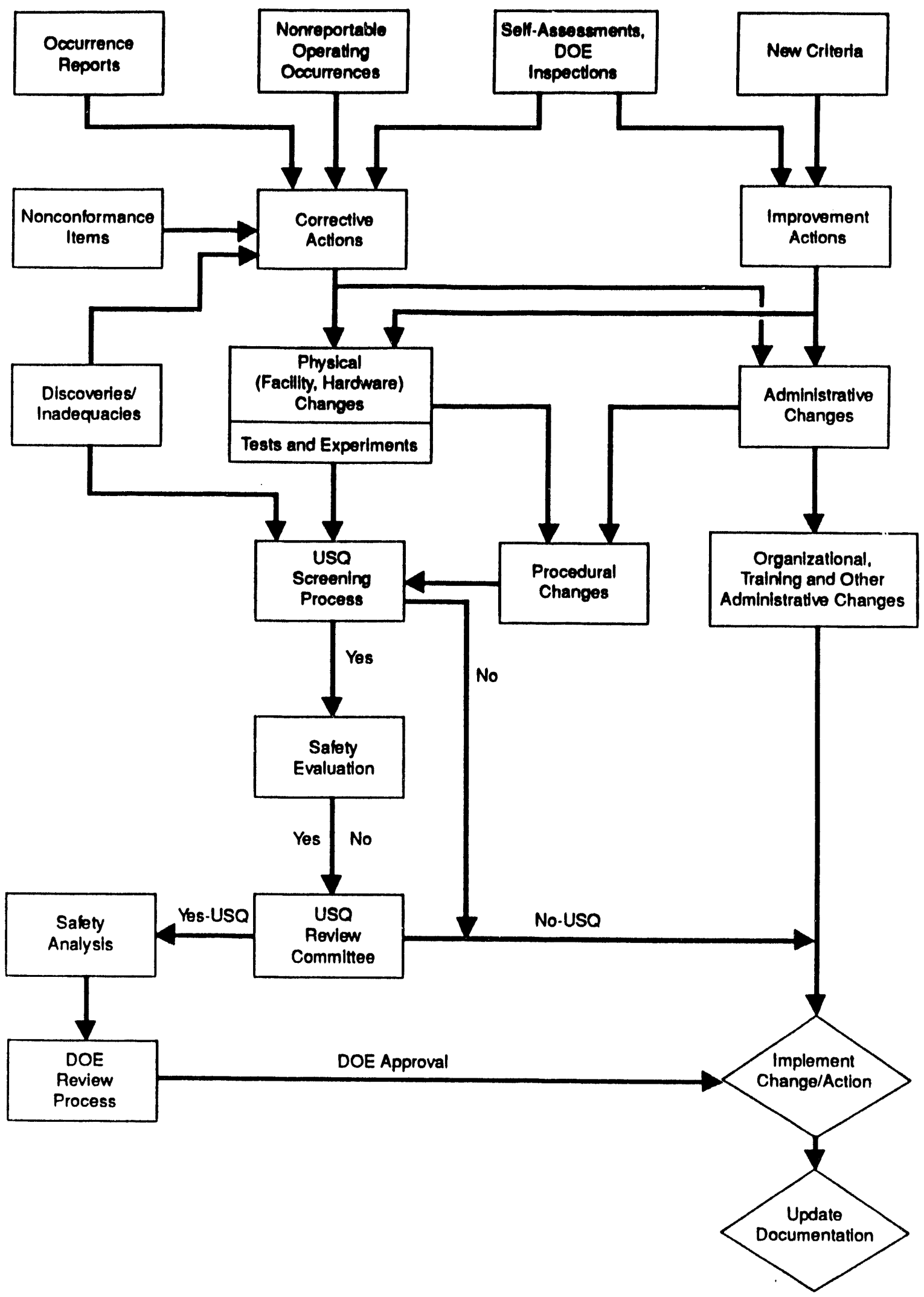


A thorough in-house review of ICPP systems identified the need to 1 imit the acid concentration in the hexone extraction, hexone recovery, hexone storage, and overall rework systems to $3 \mathrm{M} \mathrm{HNO}_{3}$. The $3 \mathrm{M}$ limit al so applies to the

$2 / 3$ cycle extraction raffinate tanks. To implement this limit, the following changes were made to the technical requirements when organics are present in the affected system.

- The hexone storage system (T-Cell) is now limited to $3 \mathrm{M} \mathrm{HNO}_{3}$.

- The rework system ( $\mathrm{L} \mathrm{Cell)} \mathrm{is} \mathrm{now} \mathrm{limited} \mathrm{to} 3 \mathrm{M} \mathrm{HNO}_{3}$.

- Sections were added to the basis of the technical requirements to reflect the new requirements.

Implementation is provided by the operational run plan and the operating procedures. These changes were reviewed by the TOMSK -7 lessons-learned review team. No unacceptable risks were identified and implementing the new 1 imits is not expected to delay the ongoing phaseout. 
WHC-EP-0693 Rev. 0

This page intentionally left blank. 
WHC-EP-0693 ReV. 0

\subsection{WASTE MANAGEMENT}

Waste generated during the phaseout/deactivation for PUREX/UO 3 and ICPP will be managed in accordance with DOE Orders 5400.1, General Environmental Protection Program," 5400.3, Hazardous and Radioactive Waste Program, and 5820. A, Radioactive Waste Management, , the Resource Conservation and Recovery Act of 1976 (RCRA), and the Washington Administrative Code (WAC) "Dangerous Waste Regulations," (WAC 173-303). This section describes the handling, treatment, and disposal of waste, and summarizes the techniques that are planned for waste minimization during the project.

\subsection{WASTE MINIMIZATION}

Waste minimization programs have been implemented for phaseout/ transition. Waste minimization objectives have been incorporated during planning to ensure that the waste minimization techniques are fully integrated into the work. The waste minimization objectives for transition, which are applied sequentially to the work, are as follows.

- Avoid generating waste

- Minimize the waste that is generated

- Recycle what is minimized

- Treat the waste that cannot be recycled.

Practical waste minimization efforts include eliminating characteristic hazardous waste, segregating wastes into compatible categories, compacting solid waste, and concentrating dilute liquid waste. Key waste minimization activities are described in the following paragraphs.

Currently, there are 3 liquid and 13 gaseous effluent discharges from PUREX and the $\mathrm{UO}_{3} \mathrm{Plant}$. By project completion, the liquid effluent discharges to the soil column and the three $\mathrm{UO}_{3} \mathrm{Plant}$ gaseous effluent discharges will have been eliminated. The 10 PUREX gaseous effluents will be consolidated into a single stream and significantly reduced in flow.

During transition, solid waste volumes will be minimized by incorporating the waste minimization objectives into the transition plan. For example, waste will be segregated by type to prevent category crossover, such as trash being converted to low-level waste through careless waste practices. In addition, compacting and reducing the size of the waste will reduce void space in the waste packages.

The generation of solid waste at PUREX and the $\mathrm{UO}_{3} \mathrm{Pl}$ ant will be el iminated after the project is complete, except for the small amounts created by surveillance entries and maintenance inside radiation zones.

Similarly, phaseout of reprocessing activities at ICPP will result in significant reduction of effluent emissions and solid waste generation. The number of effluent emission points for gaseous and liquid streams will be 
reduced by more than two-thirds and the volume of solid waste will be reduced by approximately two-thirds. A comparison of the effluent and solid reduction for operational and post deactivation/phaseout activities is presented in Table 5.

Table 5. Comparison of Waste Management Activities.

\begin{tabular}{|l|c|c|c|c|}
\hline \multirow{2}{*}{ Activity } & \multicolumn{2}{|c|}{ PUREX/UO } & \multicolumn{2}{c|}{$\begin{array}{c}\text { ICPP Phaseout } \\
\text { facilities }\end{array}$} \\
\cline { 2 - 5 } & Standby & Deactivation & $\begin{array}{c}\text { During } \\
\text { operation }\end{array}$ & Phaseout \\
\hline $\begin{array}{l}\text { Gaseous effluent discharge, } \\
\text { number of points }\end{array}$ & 13 & 1 & 24 & 7 \\
$\begin{array}{l}\text { Liquid effluent discharge, } \\
\text { number of points }\end{array}$ & 3 & 0 & 17 & 7 \\
Solid volume $\left(\mathrm{M}^{3} / \mathrm{yr}\right)$ & 2,400 & Minimal* & 345 & 120 \\
\hline
\end{tabular}

*Waste generated by quarterly surveillance and limited maintenance. 


\subsection{SAVINGS THROUGH SHARING}

The Westinghouse GOCO committee on facility transition, initiated by WEC, is a key activity for promoting savings through sharing. The committee, which is made up of representatives from al1 WEC GOCO contractors, forms the bas is for the managerial, technical, and compliance interfaces.

Savings through sharing is an ongoing WEC activity at WEC.Some accomplishments made by saving through sharing include the following.

- The ICPP Phaseout Plan (reference) was reviewed independently by WHC to ensure that lessons learned for PUREX cleanout/standby were incorporated.

- Excess PUREX aluminum nitrate nonahydrate chemicals were shipped to ICPP and consumed as part of the ICPP process.

- Other intersite support is in progress such as excess PUREX organic use at ICPP.

Past experience and ongoing work such as the decommissioning and decontamination at West Valley Nuclear Fuel Services provides additional opportunity for savings at other Westinghouse facilities. Actual savings may take the form of reduced cost to the government but may also be in the form of improved worker safety and reduced environmental impact.

The key to the success of savings through sharing is the close cooperation and communication provided by the GOCO committee on facility transition. The committee plans quarterly information exchanges to foster direct communication between the DOE site contractor personnel. 
WHC-EP-0693 Rev. 0

This page intentionally left blank.

$7-2$ 
WHC-EP-0693 ReV. 0

\subsection{REFERENCES}

DOE, 1987, Project Management System, DOE Order 4700.1, U.S. Department of Energy, Washington, D.C.

DOE, 1988, Radioactive Waste Management, DOE Order 5820.2A, U.S. Department of Energy, Washington, D.C.

DOE Order 5480.23, The Crosswalk Documentation

National Environmental Policy Act of 1969, 42 USC 4321, et seq.

Parkman, D. B., 1992, Applicability of PUREX Operational Safety Requirements During Shutdown/Standby, WHC-SD-CP-OSR-006, Westinghouse Hanford Company, Richland, Washington.

Resource Conservation and Recovery Act of 1976, 42 USC 6901, et seq.

Roemer, J. J., 1990, PUREX Plant Final Safety Analysis Report, WHC-SD-HS-SAR-001, (FSAR), Westinghouse Hanford Company, Richland, Washington.

State Environmental Policy Act of 1983, Revised Code of Washington 43.21c, 0lympia, Washington.

WAC 173-303, 1990, "Dangerous Waste Regulations," Washington Administrative Code, as amended.

Walser, R. L., 1992, Application of Standardized Operational Safety Requirement Criteria to PUREX Operational Safety Requirements, WHC-SD-CP-RD-020, (Split Report), Westinghouse Hanford Company, Richland, Washington.

WHC, 1993, PUREX/UO, Deactivation Project Management Plan, WHC-SP-1011, Westinghouse Hanford Company, Richland, Washington.

WHC-CM-5-24, PUREX Process Control Manual (PCM), Westinghouse Hanford Company, Richland, Washington.

WINCO, 1992, Nuclear Fuel Reprocessing Phaseout Plan for ICPP, Westinghouse Idaho Nuclear Corporation, Idaho Falls, Idaho.

WINCO, 1993, ICPP Final Safety Analysis Report, WIN-107 (IPM-II), Westinghouse Idaho Nuclear Corporation, Idaho Falls, Idaho. 
WHC-EP-0693 Rev. 0

This page intentionally left blank. 
WHC-EP-0693 Rev. 0

\section{DISTRIBUTION}

Number of Copies

OFFSITE

9

Westinghouse Idaho Nuclear Company P. 0. Box 4000

Idaho Falls, ID 83401

S. M. Halupa

$52-33$

K. E. Ryan

$52-29$

L. M. Kostelnik

$32-05$

D. A. Scmidt

$51-19$

M. W. Patterson (3)

52-01

Westinghouse Savannah River Company P. 0. Box 616

Aiken, SC 29802

G. H. Street

West Valley Nuclear Services

P. 0. Box 191

West Valley, NY 14171-0191

D. H. Kurasch

ONSITE

2

U.S. Department of Energy

Richland Operations Office

G. J. Bracken

R3-81

Public Reading Room

Al -65

1

Pacific Northwest Laboratory

Technical Files

$\mathrm{K} 1-11$

13

Westinghouse Hanford Company

R. J. Bliss

B3-04

W. W. Bowen

$\mathrm{N} 1-03$

D. G. Hamrick

S5-15

D. G. Harlow

S6-17

J. R. Knight

B3-04

J. F. Oswald

B3-03

R. J. Thompson

S6-17

Central Files (2)

L8-04

Document Processing and Distribution

L8-15

Information Release Administration (3)

Rl-05

$$
\text { Distr-1 }
$$


WHC-EP-0693 Rev. 0

This page intentionally left blank.

Distr-2 
